OPEN ACCESS

Edited by:

Juan José Lasarte, Centro de Investigación Médica Aplicada (CIMA), Spain

Reviewed by:

Cosima T. Baldari,

University of Siena, Italy Daniella Areas Mendes-da-Cruz, Oswaldo Cruz Foundation, Brazil Gabriela Schneider,

University of Louisville, USA

*Correspondence:

Carole A. Oskeritzian carole.oskeritzian@uscmed.sc.edu; Sergio E. Alvarez sealvarez98@gmail.com

Specialty section: This article was submitted to Molecular and Cellular Oncology, a section of the journal Frontiers in Oncology

Received: 08 August 2016 Accepted: 30 September 2016

Published: 17 October 2016

Citation:

Rodriguez YI, Campos LE, Castro MG, Aladhami A, Oskeritzian CA and Alvarez SE (2016) Sphingosine-1 Phosphate: A New Modulator of Immune Plasticity in the Tumor Microenvironment.

Front. Oncol. 6:218. doi: $10.3389 /$ fonc.2016.00218

\section{Sphingosine-1 Phosphate: A New Modulator of Immune Plasticity in the Tumor Microenvironment}

\author{
Yamila I. Rodriguez', Ludmila E. Campos', Melina G. Castro', Ahmed Aladhami', \\ Carole A. Oskeritzian ${ }^{2 *}$ and Sergio E. Alvarez ${ }^{1,3 *}$ \\ ${ }^{1}$ Instituto Multidisciplinario de Investigaciones Biológicas San Luis (IMIBIO-SL) CONICET, San Luis, Argentina, ${ }^{2}$ Department \\ of Pathology, Microbiology and Immunology, University of South Carolina School of Medicine, Columbia, SC, USA, \\ ${ }^{3}$ Universidad Nacional de San Luis, San Luis, Argentina
}

In the last 15 years, increasing evidences demonstrate a strong link between sphingosine-1-phosphate (S1P) and both normal physiology and progression of different diseases, including cancer and inflammation. Indeed, numerous studies show that tissue levels of this sphingolipid metabolite are augmented in many cancers, affecting survival, proliferation, angiogenesis, and metastatic spread. Recent insights into the possible role of S1P as a therapeutic target has attracted enormous attention and opened new opportunities in this evolving field. In this review, we will focus on the role of S1P in cancer, with particular emphasis in new developments that highlight the many functions of this sphingolipid in the tumor microenvironment. We will discuss how S1P modulates phenotypic plasticity of macrophages and mast cells, tumor-induced immune evasion, differentiation and survival of immune cells in the tumor milieu, interaction between cancer and stromal cells, and hypoxic response.

Keywords: sphingosine-1-phosphate, tumor microenvironment, inflammation, metastasis, macrophage polarization

\section{SPHINGOSINE-1-PHOSPHATE}

Sphingosine-1-phosphate (S1P) is a bioactive sphingolipid metabolite that regulates several physiological processes, including cell growth, survival, migration, differentiation, activation, and immune responses. Considering the diversity of the actions of S1P, it is predictable that deregulation of its many functions may result in the development of pathological conditions. Certainly, S1P plays important roles in cancer and disorders of the immune system. Intracellular S1P levels are tightly regulated by the equilibrium between its formation, catalyzed by sphingosine kinases (SphKs), and degradation, catalyzed by S1P lyase (SPL) and S1P phosphatases (SPPs). Two isozymes of mammalian SphK have been cloned and characterized, SphK types 1 and 2 (SphK1 and SphK2) (1). Interestingly, S1P can be exported out of the cell either by the specific transporter Spinster 2 (Spns2) (2) or by several members of the $\mathrm{ABC}$ transporter family (3). In turn, S1P exerts extracellular functions through the binding to five specific G-protein-coupled receptors (GPCR), named S1P receptors (S1PR) 1-5 $(1,4)$. This autocrine and/or paracrine action of S1P is known as "inside-out signaling" $(1,5)$ and is critical for a great variety of cellular responses. Although most of the known actions of S1P are mediated by S1PRs, in the last few years, it has become evident that S1P also exerts intracellular functions by targeting different molecules (Figure 1). 


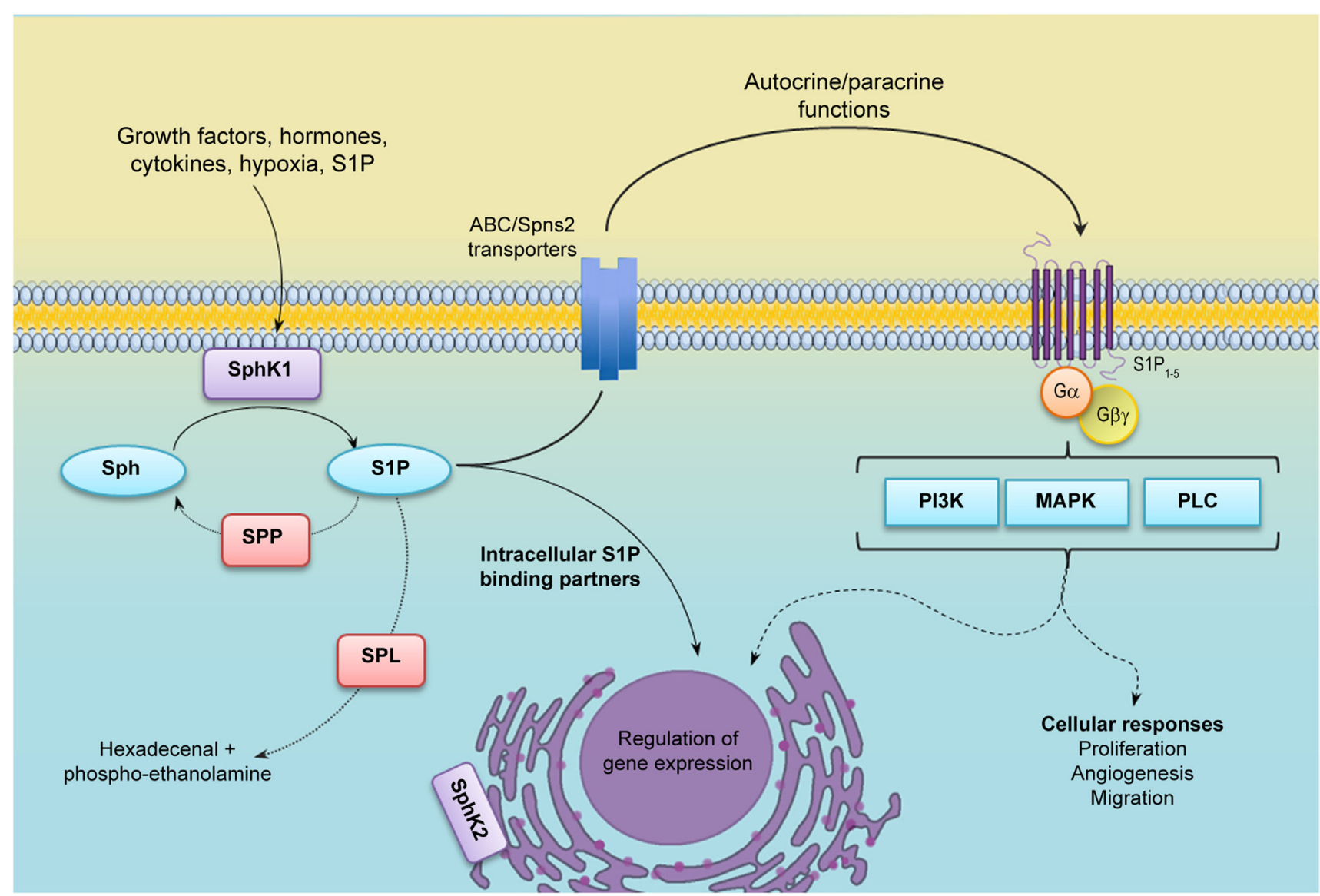

FIGURE 1 | S1P metabolism and inside-out signaling. Many agonists stimulate cytosolic sphingosine kinase 1 (SphK1), which translocates to the plasma membrane and uses sphingosine as a substrate to generate Sphingosine-1-phosphate (S1P). S1P may be irreversibly degraded by S1P lyase (SPL) or dephosphorylated by S1P phosphatases (SPPs). After being secreted out by specific transporters, S1P binds and activates S1P receptors (S1PR1-5) in an autocrine or paracrine manner and regulates many cellular functions (inside-out signaling). S1P may also function as an intracellular second messenger through the binding of different intracellular partners. Abbreviations: PI3K, phosphatidylinositol 3-kinase; MAPK, mitogen-activated protein kinases; PLC, phospholipase C.

\section{THE COMPLEXITY OF S1P SIGNALING}

Many distinct agonists, including cytokines, growth factors, and hormones, among others, induce translocation of SphK1 to the plasma membrane, where its substrate sphingosine resides, leading to the activation of the enzyme. SphK1 translocation depends on its phosphorylation at Ser 225 by ERK1/2 (6) and interaction with calcium and integrin-binding protein 1 (CIB1) (7). Indeed, a mutation of SphK1 on Ser225 residue behaves as a dominant negative, although the protein maintains its kinase activity (6). SphK1 translocation also results in the production of S1P in a location that allows its extracellular export, making it readily available for ligation of S1PRs to trigger the "insideout" signaling. On the other hand, SphK2 is located in several organelles, including the nucleus and endoplasmic reticulum (Figure 1). Although much less is known about SphK2 activation (8), it is also phosphorylated and activated by ERK1 (9). Likewise, SphK2 is phosphorylated by protein kinase D (PKD) in HeLa cells, leading to nuclear export and cytoplasm accumulation of the enzyme (10).
$\mathrm{S} 1 \mathrm{P}$ receptors are coupled to distinct heterotrimeric $\mathrm{G}$ proteins leading to downstream activation of diverse effector pathways, including phospholipase C (PLC), phosphatidylinositol 3-kinase (PI3K), and mitogen-activated protein kinases (MAPK), among others (11). The functional response of each cell to S1P varies depending on its S1P receptor repertoire that is also modulated by several signals (12).

$\mathrm{S} 1 \mathrm{P}$ receptor- 1 has a central role in cell migration and it is undoubtedly involved in angiogenesis and immune cell trafficking. A gradient of S1P characterizes physiological conditions, where S1P levels are elevated in blood and lymph and low in tissues. This gradient is important for vascular integrity and allows immune cell egress from lymphoid organs to the circulation (13). Furthermore, high S1P levels produced during inflammatory processes drive immune cell recruitment to inflamed tissues. During embryonic development (14) and tumor progression, the S1P/S1PR1 axis promotes endothelial precursor recruitment and vascular development. The crucial role of S1PR1 in lymphocyte migration culminated by the rapid development of FTY-720 (fingolimod) as an immunosuppressive drug, approved by the Food 
and Drug Administration (FDA) for the treatment of recurrent form of multiple sclerosis (MS). FTY-720 induces S1PR1 endocytosis and degradation, thus preventing lymphocyte egress and inflammation, a hallmark of MS (15).

For the most part, binding of S1PR1 has been shown to promote migration of several cancer cell lines (16-19), while S1PR2 exerted opposite effect (20-22). Indeed, stimulation (16) or inhibition (23) of S1P-induced migration in melanoma cells depends on expression of S1PR1 or S1PR2, respectively. However, some reports also established a positive role of S1PR2 in migration $(24,25)$, indicative of a complex role of S1PRs in cell motility. Similar to S1PR1, engagement of S1PR3 promotes migration. Certainly, a role of S1PR3 in cell motility has been described for bone marrow-derived mesenchymal stem cells (26), human breast cancer cells (27), and endothelial progenitor cells (28), which are important in tumor angiogenesis. Furthermore, in gastric cancer cells, the balance between S1PR3 and S1PR2 expression is a critical feature to decide whether the cell will increase (S1PR3) or decrease (S1PR2) its migratory capability (29).

Expressions of S1PR4/5 are more limited, and the mechanisms that they regulate are less understood. However, it is known that S1PR4 promotes neutrophil trafficking (30) and dentritic cell differentiation (31), while S1PR5 has been associated with natural killer (NK) cell trafficking $(32,33)$.

Many studies, in the past few years, have clearly demonstrated that S1P can also function as an intracellular mediator. Dr. Spiegel's group has shown that S1P binds and modulates the function of different intracellular targets, including tumor necrosis factor (TNF) receptor-associated factor 2 (TRAF2) (34), histone deacetylases, HDAC1 and HDAC2 (35), and prohibitin 2 (36). Recent reports also indicate that S1P binds peroxisome proliferator-activated receptor gamma (PPAR $\gamma)$ in endothelial cells and stimulates angiogenesis (37).

A comprehensive description of S1P signaling is out of the scope of this review, but the reader is encouraged to read some excellent reviews published recently $(5,11,38)$.

\section{THE MANY FUNCTIONS OF S1P IN CANCER}

About 20 years ago, two seminal papers described, for the first time, the role of S1P in enhancing proliferation and inhibiting apoptosis $(39,40)$. Since then, many studies have reinforced a pro-survival function of S1P. On the contrary, ceramide and sphingosine are usually associated with cell growth arrest. The inter-convertibility of these metabolites has led to the concept of "sphingolipid rheostat," with the balance between S1P vs. sphingosine and ceramide levels, determining cell survival or death (41). Considering its role as growth promoter, it is not surprising that many evidences strongly support a fundamental role of S1P in cancer progression.

\section{S1P Metabolizing Enzymes in Cancer}

It has been demonstrated that S1P levels and SphK1 expression and/or activity are increased in distinct cancer types (42). Table 1 summarizes some of the known cancer types and the biological effects associated to deregulated expression of the enzymes involved in S1P metabolism. Although beyond the scope of this review, these findings have been substantiated by in vitro studies using pharmacological and molecular tools. Thus, inhibition of SphK1 activity with corresponding decrease of S1P levels induced apoptosis in acute myeloid leukemia (AML) cells $(43,44)$, and diminished in vivo cell growth of ovarian cancer (45). Importantly, in ovarian cancer, the mTORC1/2 inhibitor WYE-132 reduced SphK1 activity, which induced cytotoxicity and diminished in vivo cell growth (45).

Interestingly, microRNAs ( $\mathrm{miR}$ ), which may act as oncogenes or tumor suppressors, also regulate the expression of SphK1. In that regard, miR-506 suppressed tumor angiogenesis through targeting SphK1 mRNA in liver cancer (77), while miR-124 downregulated SphK1 and inhibited proliferation of gastric cancer cells (78). miR-124 expression inversely correlated with metastasis and SphK1 in ovarian cancer, suggesting that downregulation of miR124 may be a common mechanism to modulate S1P-induced cancer progression (79). Moreover, miR-613 was downregulated in papillary thyroid cancer (PTC) and inversely modulated SphK2 expression in vitro and in vivo (64). It is likely that regulation of SphKs expression by $\mathrm{miR}$ in different tissues will reveal new mechanisms and define improved cancer therapies.

In contrast to the substantial evidences that suggest a crucial role of SphK1 in cancer development, much less is known about the function of SphK2. In that sense, specific inhibition of SphK2 with ABC294640 in colorectal cancer (CRC) cells reduced S1P and increases ceramide levels, thus inhibiting CRC cells and xenografts growth in vitro and in vivo, respectively (50). Although this action seemed to be receptor-mediated, studies with specific S1PRs agonist or antagonist are lacking. Of great interest, low dose of ABC294640 was able to sensitize cells, making them more susceptible to chemotherapeutic treatment $(80,81)$. In addition, ABC294640 has been also found to effectively inhibit proliferation and xenograft prostate tumor growth by targeting the androgen receptor and the proto-oncogene myc (81). Indeed, SphK2 was upregulated in acute lymphoblastic leukemia and induced the expression of Myc, suggesting an important role in hematological cancers (46). Downregulation of SphK2 by small interfering RNA also reduced migration of T24 human bladder carcinoma (82), MDA-MB-231 breast cancer, and A-498 kidney carcinoma cells (83). Altogether, these evidences unwrap a new opportunity to consider SphK2 as a potential target, not only to inhibit cancer progression but also to prevent tumor resistance to standard chemotherapy.

Alterations in S1P metabolism and levels are not only regulated by SphKs but also by SPPs and SPL. In line with the cancer-supporting role of S1P, reduced expression of SPPs led to augmented S1P levels and is also a common feature of different tumors. In fact, downregulation of SPP1 in gastric cancer tissues enhanced metastasis (73), suggesting that SPP1 expression may serve as a prognostic marker in gastric cancer that correlates with patient's survival (73). Also, the increased S1P content detected in human glioblastoma tissue was associated with SphK1 expression but inversely correlated with SPP2 expression, suggesting that the shift of the S1P rheostat may play a role in the development of this tumor (74). SPL is downregulated in prostate and colon 
TABLE 1 | List of S1P-related proteins deregulated in distinct cancer types.

\begin{tabular}{|c|c|c|c|}
\hline Cancer type & $\begin{array}{l}\text { Deregulation SphKs/ } \\
\text { S1PRs }\end{array}$ & Biological significance & Reference \\
\hline $\begin{array}{l}\text { Acute lymphoblastic } \\
\text { leukemia }\end{array}$ & $\uparrow$ SphK2 expression & $\begin{array}{l}\text { Mice: SphK2 }{ }^{-/-} \text {animals display reduced leukemia. In vitro: inhibition of SphK2 suppresses } \\
\text { proliferation and induces apoptosis }\end{array}$ & $(46)$ \\
\hline Astrocytome & $\uparrow$ SphK1 expression & In vivo: patients exhibit shorter survival time & $(47)$ \\
\hline Breast cancer ER-negative & $\begin{array}{l}\uparrow \text { SphK1 and S1PR4 } \\
\text { expression }\end{array}$ & In vivo: shorter disease-specific survival & $(48)$ \\
\hline Breast cancer ER-positive & $\begin{array}{l}\uparrow \text { SphK1, S1PR1, and } \\
\text { S1PR3 expression }\end{array}$ & In vivo: increase tamoxifen resistance & $(49)$ \\
\hline Colorectal cancer & $\uparrow$ SphK1 expression & $\begin{array}{l}\text { In vivo: increase lymph node and liver metastasis, and advanced TNM stage. In vitro: SphK1 } \\
\text { knockdown inhibits cell proliferation and invasion }\end{array}$ & $(50,51)$ \\
\hline Gastric cancer & $\uparrow$ SphK1 expression & In vivo: decrease survival & $(52)$ \\
\hline Glioblastoma multiforme & $\begin{array}{l}\uparrow \text { SphK1, S1PR1, } \\
\text { S1PR2, and S1PR3 } \\
\text { expression }\end{array}$ & $\begin{array}{l}\text { In vivo: poor prognosis and survival in patients. In vitro: inhibition of SphK reduces cell viability; } \\
\text { inhibition of S1PR1 and S1PR2 diminishes cell migration }\end{array}$ & $(53-55)$ \\
\hline $\begin{array}{l}\text { Head and neck squamous } \\
\text { cell carcinoma }\end{array}$ & $\uparrow$ SphK1 expression & Mice: SphK $1^{-1-}$ animals display less tumor incidence and volume & $(56)$ \\
\hline Hepatocellular carcinoma & $\begin{array}{l}\uparrow \text { SphK } 1 / 2 \text { and SPL } \\
\text { expression; } \downarrow \text { S1P levels }\end{array}$ & $\begin{array}{l}\text { In vivo: poorer tumor differentiation, increase microvascular invasion, and earlier recurrence. } \\
\text { In vitro: inhibition of SphKs or SPL expression reduces cell proliferation, invasion, and migration }\end{array}$ & $(57)$ \\
\hline Large B-cell lymphoma & $\downarrow$ S1PR2 & Human: S1PR2 somatic mutations were found in large B-cell lymphoma samples & $(58)$ \\
\hline Liver cancer & $\uparrow$ SphK1 expression & Mice and in vitro: downregulation of SphK1 inhibits angiogenesis & $(59)$ \\
\hline Melanoma & $\uparrow$ SphK1 activity & $\begin{array}{l}\text { Mice: SphK1 inhibition decreases melanoma cell growth. In vitro: SphK1 inhibition retards } \\
\text { melanoma cell growth }\end{array}$ & $(60)$ \\
\hline Nasopharyngeal carcinoma & $\uparrow$ SphK1 expression & In vivo: SphK1 is related to clinical stage and distant metastasis & $(61)$ \\
\hline Non-Hodgkin lymphomas & $\uparrow$ SphK1 expression & In vivo: increase clinical grade & $(62)$ \\
\hline Pancreatic cancer & $\uparrow$ SphK1 expression & In vivo: poor prognosis & (63) \\
\hline Papillary thyroid cancer & $\uparrow$ SphK2 expression & In vivo: SphK2 expression correlates with clinical stage & $(64)$ \\
\hline \multirow[t]{2}{*}{ Prostate cancer } & $\uparrow$ SphK1 activity & $\begin{array}{l}\text { Human: } 2 \text {-fold increase of SphK1 activity in human prostate Ca section vs. normal counterpart. } \\
\uparrow \text { PSA, } \uparrow \text { tumor volume, } \uparrow \text { treatment failure were associated with increased SphK1 activity }\end{array}$ & $(65)$ \\
\hline & Neutralization of S1P & $\begin{array}{l}\text { In vivo: in orthotopic xenograft model of human PC-3 prostate cancer cells, anti-S1P } \\
\text { monoclonal } \mathrm{Ab}\left(\text { Sphingomab }{ }^{\circledR}\right) \text { inhibited intratumoral hypoxia, induced vascular remodeling and } \\
\text { chemotherapy sensitivity }\end{array}$ & $(66)$ \\
\hline Thyroid cancer & $\uparrow$ SphK1 expression & In vivo: increased proliferation. In vitro: silencing of SphK reduces cell proliferation & $(67)$ \\
\hline $\begin{array}{l}\text { Triple-negative breast } \\
\text { cancer }\end{array}$ & $\uparrow S p h K 1$ expression & $\begin{array}{l}\text { In vivo: decrease patient survival. In vitro: knockdown of SphK1 diminishes cell proliferation and } \\
\text { migration/invasion }\end{array}$ & $(18,68)$ \\
\hline Uterine cervical cancer & $\uparrow$ SphK1 expression & $\begin{array}{l}\text { In vivo: aggressive oncogenic behavior, invasion, and lymph node metastasis. In vitro: inhibition } \\
\text { of SphK1 reduces cell viability and increases apoptosis }\end{array}$ & (69) \\
\hline Wilm's tumor (renal cancer) & $\uparrow \mathrm{S} 1 \mathrm{PR} 2$ & Human: S1PR2 mRNA overexpressed in Wilm's tumor samples & $(70)$ \\
\hline Cancer type & $\begin{array}{l}\text { Deregulation of other } \\
\text { S1P-related proteins }\end{array}$ & Biological significance & Reference \\
\hline Colon cancer & $\begin{array}{l}\downarrow \text { SPL and SPP } \\
\text { expression }\end{array}$ & $\begin{array}{l}\text { Human: SPL expression downregulated in colon cancer tissue. In mice: SPL }{ }^{-/-} \text {increased } \\
\text { susceptibility to CAC. In vitro: SPL downregulation diminished stress-induced apoptosis. SPL } \\
\text { overexpression had opposite response }\end{array}$ & $(71,72)$ \\
\hline Gastric cancer & $\downarrow$ SPP expression & $\begin{array}{l}\text { Human: SPP (protein and mRNA) was downregulated in cancer tissue and correlated with } \\
\text { metastasis. In vitro: SPP knockdown increased invasion and migration. SPP overexpression } \\
\text { induced slow growth and less adhesion }\end{array}$ & $(73)$ \\
\hline Glioblastoma & $\begin{array}{l}\downarrow \text { SPP2 and } \uparrow \text { SphK1 } \\
\text { expression }\end{array}$ & $\begin{array}{l}\text { Human: increased S1P and decreased ceramide content; high SphK1 and low SPP2 expression } \\
\text { in cancer tissue. In vitro: Sphk1 inhibition reduced angiogenesis in a coculture model }\end{array}$ & $(74)$ \\
\hline Lung cancer & $\downarrow$ Spns2 expression & $\begin{array}{l}\text { Human: Spns } 2 \text { mRNA is reduced in advance lung cancer. In vitro: ectopic Spns2 expression } \\
\text { induced apoptosis, modulates S1P metabolism and S1PRs expression }\end{array}$ & $(75)$ \\
\hline Prostate cancer & $\begin{array}{l}\downarrow \text { SPL expression and } \\
\text { activity }\end{array}$ & $\begin{array}{l}\text { Human: low SPL and high Sphk1 expression are correlated with aggressiveness and poor } \\
\text { prognosis. In vitro: SPL downregulation enhanced cell survival after radio and chemotherapy, } \\
\text { while SPL overexpression had opposite effects }\end{array}$ & $(76)$ \\
\hline
\end{tabular}


cancer $(71,72,76)$, and it was shown to have an implication in chemo and radiotherapy resistance (76), implying that regulation of SPL activity might be a novel approach to cancer treatment. Furthermore, deletion of SPL in intestinal epithelium provoked an increased incidence of colitis-associated cancer and enhanced inflammatory response in mice (72). Interestingly, the expression of the specific S1P transporter, Spns2, was also reduced in advance lung cancer patients (75). On the contrary, over expression of Spns2 induced apoptosis in non-small cell lung cancer (NSCLC) cells (75). Although it is clear that the evidences are less abundant in comparison with SphKs, these findings suggest that the modulation of S1P-degrading enzymes and S1P transporter might constitute a new therapeutic option.

Even an overwhelming amount of data indicate that increased S1P levels were associated with cancer progression, many recent reports showed disconcerting results: (i) in patients with hepatocellular carcinoma, a decrease in S1P levels in HCC tissue was linked to less tumor differentiation and more microvascular invasion (57); (ii) specific inhibition of SphK1 in 1483 head and neck carcinoma cells with PF-543 did not affect cell proliferation or survival (84), and (iii) pharmacological and molecular inhibition of SphK1 and SphK2 did not affect tumor cell growth, both in vitro and in vivo (85). The discrepancies of these results with many opposing evidences warrant further investigation. Nonetheless, it is important to highlight that PF-543 exerted anti-proliferative effects in diverse CRC cell lines, suggesting differential and tissuedependent functions for SphK1 (86).

\section{S1PRs and Cancer}

Similar to SphKs, deregulation of S1PRs expression is frequently observed in many cancer types and may account for significant differences in tumor angiogenesis and invasiveness. In glioblastoma multiforme (GBM), one of the brain tumors with worse prognosis, increased expression of S1PR1 and S1PR2 correlated with decreased patient's survival (53). In human pancreatic cells, $\mathrm{S} 1 \mathrm{P}$ also increased proliferation and migration through a mechanism that involves activation of c-Src pathway (87). A very recent report showed that activation of S1PR2 in epithelial cells was crucial for elimination of neighboring cancer cells, a process known as epithelial defense against cancer (EDAC) (88). Of great interest, the process involved a gradual accumulation of Filamin A (FlnA), an actin-binding protein that we recently demonstrated to modulate S1P-induced NF- $\kappa \mathrm{B}$ activation in melanoma cells (89).

A central role of S1P in tumor progression has been further highlighted by the development of Sphingomab ${ }^{\circledR}$, a neutralizing anti-S1P monoclonal antibody (90) that prevents signaling through all S1PRs. Exciting studies in xenograft models showed that Sphingomab reduced blood vessel formation and tumor-associated angiogenesis (90). Furthermore, this antibody blocked hypoxia-inducible factor $1 \alpha$ (HIF-1 $\alpha$ ) accumulation in low-oxygen environments and modified vessel architecture, leading to an improved sensitivity to chemotherapeutic drugs in an in vivo model of prostate cancer (66) and sunitinib-resistant renal cancers (91).

More recently, the development of Spiegelmers ${ }^{\circledR}$, synthetic oligonucleotides built of non-natural L-nucleotides, has opened new opportunities to target S1P. Indeed, NOX-S93 is a recently identified Spiegelmer ${ }^{\circledR}$ that binds S1P in the low nanomolar range and blocks the angiogenic activity of the lipid and vascular endothelial growth factor (VEGF) (92). Moreover, preclinical data indicate that NOX-S93 reduces S1P-induced metastasis of Rhabdomyosarcoma (RMS) (93). Thus, strong evidences suggest that S1P inhibition may be a prospective strategy to deprive cancer cells from basic nutrients and diminish tumor growth and chemotherapy resistance.

\section{S1P Is a Putative Prognostic Factor}

Sphingosine-1-phosphate has recently gained additional significance through many reports, suggesting that it may serve as a prognostic factor in different kind of tumors. In fact, increased SphK1 expression was associated with tumor size, lower survival, recurrence and poor prognosis in HCC, astrocytoma, and breast cancer patients $(47,48,94)$. Moreover, in uterine cervical cancer, SphK1 expression was correlated with invasion and lymph node metastasis (69). Intriguingly, plasma levels of S1P were lower in prostate cancer patients than in healthy controls, perhaps due to the reduced expression of SphK1 subsequent to decreased hematocrit featured in cancer patients (95). There is no doubt that substantiation of these findings in other types of cancers may shed some light about possible clinical implications and use of $\mathrm{S} 1 \mathrm{P}$ as a cancer biomarker.

\section{S1P and Cancer Chemoresistance}

Accumulating evidences imply that S1P may have a potential role in cancer chemoresistance, one of the main causes of poor treatment outcome and tumor relapse. For instance, CRC cells with acquired resistance to cetuximab, an epidermal growth factor receptor (EGFR) inhibitor, overexpressed SphK1, and its inhibition re-established sensitivity to the drug. These findings were corroborated in CRC patients whose SphK1 overexpression also resulted in resistance to cetuximab (96). Similarly, both expression and activity of SphK1 were increased in sunitinib-resistant renal cell lines (97), and a gene-expression analysis of different tumor cell lines resistant to oxaliplatin, cisplatin, and docetaxel identified that drug resistance was related to SphK1 expression (98). These evidences support the relevance of ongoing clinical trials with combinational therapies of safingol (SphK1 inhibitor) and classic chemotherapeutic drugs.

In agreement, many reports suggest that other proteins involved in S1P signaling may also serve as potential targets to overcome resistance to chemotherapy. Thus, SphK2 overexpression has been correlated to gefitinib chemoresistance in NSCLC cells (99), and to proliferation of chemoresistant hormone-independent breast cancer (80), while in cisplatin-resistant melanoma cells, combined treatment with the S1PR modulator FTY720 and cisplatin induced cell death (100).

Indeed, increase in S1P levels seems to be crucial to chemotherapy resistance. Thus, preventing S1P degradation by SPL silencing in prostate cell lines enhanced survival after chemotherapy and radiation (76). In agreement, levels of S1P were also increased in metastasic sites of RMS cells inoculated in mice treated with chemotherapy or $\gamma$-irradiation (93). Therefore, 
S1P may be important in establishing a microenvironment that facilitates metastasis after standard tumor treatments.

Taken together, these data strongly support the "sphingolipid rheostat" concept and indicate that modulation of S1P, ceramide, and sphingosine levels may constitute a promising anti-cancer therapy, but it also suggests that controversy still exists pertaining to the exact role of $\mathrm{S} 1 \mathrm{P}$ in tumor progression. In that sense, it is possible that differential functions of S1P in distinct cancer types may be related not only to the regulation of the tumor cell but also to its role as a factor present in the tumor microenvironment.

\section{S1P AS A MODULATOR OF THE TUMOR MICROENVIRONMENT}

Since Virchow proposed that tumors behave like wounds that do not heal (101), a link between inflammation and cancer has been extensively studied, but it was not widely understood until recently (102). The tumor microenvironment is populated by tumor cells and non-neoplastic stromal cells as lymphocytes, macrophages, dendritic cells (DC), fibroblasts, mast cells (MC), and endothelial cells, among others. They can interact by direct cell-cell contact or they may communicate through soluble factors. Indeed, many evidences demonstrate that the tumor microenvironment has an important role in allowing the tumor to express its full neoplastic phenotype by increasing angiogenesis and metastasis.

\section{Monocyte Recruitment and Macrophage Polarization}

Inflammatory infiltrates are often a hallmark of many cancers, leading to sustained release of proinflammatory, anti-inflammatory, and immunosuppressive cytokines in the tumor microenvironment. While the initial purpose of these inflammatory cells is to fight the tumor, at the end, they may enhance cancer progression. The recruitment of macrophages to the tumor is dependent on chemokines secreted by the tumor and represents a delicate balance between the antitumor response and the production of mediators that may facilitate the growth of the tumor. Accordingly, a broad range of macrophage subsets has been described. M1 (classically) or M2 (alternatively activated) macrophages constitute the extremes of the scale. M1 macrophages kill tumor cells, whereas M2 macrophages produce angiogenic factors, anti-inflammatory cytokines, and stimulate tumor growth (103). Tumor-associated macrophages (TAM) display an M2-like phenotype and a correlation between TAM density and poor prognosis of many cancers has been clearly established. Moreover, new evidences connect TAMs with chemotherapy resistance.

Sphingosine-1-phosphate has been largely recognized as a chemoattractant lipid for many cell types, including inflammatory cells $(104,105)$. Indeed, we have shown that S1P released from apoptotic cancer cells, acted as a "come and get me" signal and attracted monocytes to almost the same extent as monocyte chemoattractant protein-1 (MCP-1/CCL2) (106) (Figure 2A). Once they reach the tissue, monocytes differentiate into macrophages. Interestingly, apoptotic cells also regulate macrophages by enhancing expression of S1PR1, which in turn is required to increase motility (107) (Figure 2A). It is well known that apoptotic cell clearance is an important regulatory mechanism that maintains homeostasis; thus, deregulation of this activity results in chronic inflammation characteristic of cancer among other diseases. The role of S1P as a signal from apoptotic cells has been well documented in the last years in many models, including erythropoiesis (108), breast cancer $(109,110)$, kidney repair (111), and acute T cell leukemia (107, $112,113)$. Mechanistically, while some reports indicated that increased release of S1P from apoptotic cells was related to SphK1 activation (106), others suggested that S1P was mainly derived from SphK2 (113). These opposite results may be due to the use of different agents to induce apoptosis: doxorubicin and SphK inhibitors induced a dramatic increase in SphK1 expression (106), while staurosporin treatment supported SphK2-induced release of S1P (113).

Notably, release of S1P from apoptotic cells has dramatic implications in macrophage polarization, cytokine release, and angiogenesis. Thus, S1P polarized macrophages toward an M2 phenotype (110), increased release of IL-10, a distinctive antiinflammatory cytokine, from TAMs $(109,110)$, and stimulated macrophages to secrete prostaglandin E2 (PGE2) that, in turn, induced migration of endothelial cells increasing angiogenesis, a seal of tumor progression (112) (Figure 2A). S1P released from apoptotic cells also induced $\mathrm{Bcl}-\mathrm{X}(\mathrm{L})$ and $\mathrm{Bcl}-2$ upregulation and protected macrophages from cell death (113). In that regard, it is attractive to speculate that $\mathrm{S} 1 \mathrm{P}$ has a dual role on macrophages: (i) cell death inhibition and (ii) induction of M2 polarization, both supporting cancer progression. Importantly, in vivo xenograft experiments suggested that growth and M2 macrophage polarization, but not total infiltration, were compromised in mice injected with MCF-7 breast cancer cells carrying a short hairpin (sh)RNA plasmid to downregulate SphK2, strongly suggesting a role for this isoform in S1P-mediated macrophage growth and M2 polarization (114). However, it has also been suggested that increased expression of SphK1 may serve as an M2 marker (115).

Although the evidences indicated above clearly support a direct role of S1P as a modulator of TAMs, recent finding suggests that its function may be even more complex than expected and may regulate the function of different ligands. In that sense, S1PR1 signaling was also required for Angiotensin II (Ang II)dependent production of TAMs in the spleen (116). To further emphasize its role as modulator of macrophage functions, direct S1P stimulation also induced M2 polarization through IL-4 secretion and signaling (117) and S1PR1-mediated decrease of proinflammatory cytokines secretion with simultaneous inhibition of inducible nitric oxide synthase (iNOS) activity and augmented arginase I activity (118) (Figure 2A).

The assumption that $\mathrm{S} 1 \mathrm{P}$ is important for both monocyte recruitment and switch toward a less aggressive macrophage phenotype may be of great utility for cancer cells to generate a permissive microenvironment and, at the same time, to evade the tumor-killing response elicited by cytotoxic macrophages. In this regard, S1P may not only promote cancer cell growth but also decrease the immune response that destroys the tumor. 


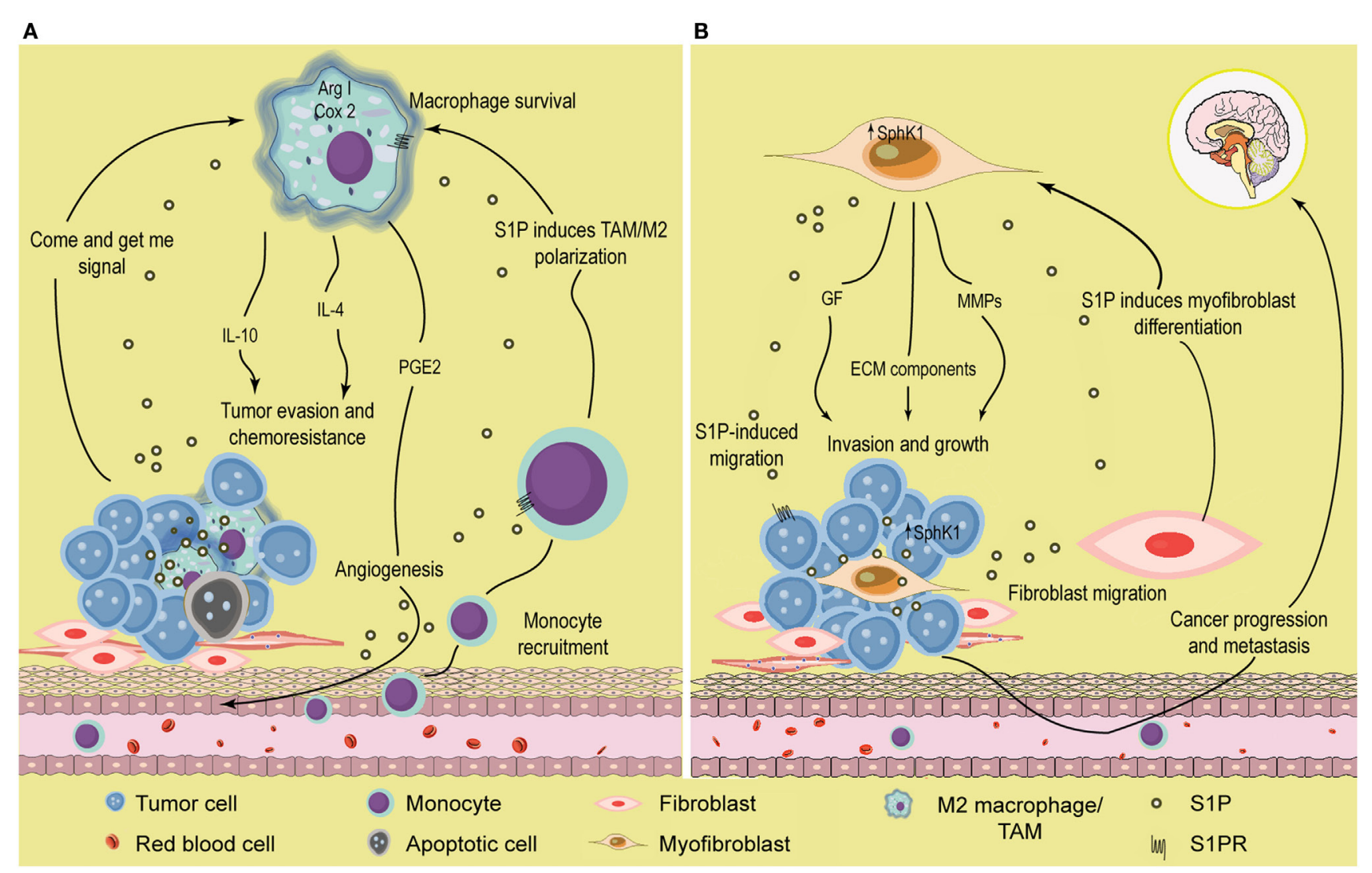

FIGURE 2 | Role of S1P in the tumor microenvironment. (A) S1P induces monocyte recruitment and macrophage polarization. Apoptotic or tumor cells release S1P that binds S1PR1 and recruits circulating monocytes toward the tumor microenvironment. Once they enter the tissues, monocytes differentiate into macrophages with distinct phenotype according to the surrounding signals. In the tumor microenvironment, S1P exhibits many functions; (i) increase macrophage survival; (ii) function as a "come and get me signaling" of dying cells to attract and enhance macrophage migration through the binding of S1PR1, and (iii) stimulate TAM/M2 macrophage polarization by activating S1PR1/2/4. TAMs are characterized by increased Arginase I (Arg I) activity and secrete the anti-inflammatory cytokines IL-4 and IL-10 that further contribute to induce a permissive microenvironment characterized by tumor evasion and chemotherapy resistance. In addition, S1P released from apoptotic cells activates S1PR1/3 in macrophages to upregulate the expression of cycloxoygenase 2 (Cox-2) and stimulate the secretion of prostaglandin E2 (PGE2) that support migration of endothelial cells and angiogenesis, a hallmark of tumor progression. (B) S1P modulates the interaction between tumor and stromal cells. SphK1 expression is upregulated in melanoma cells, increasing the production of S1P. Melanoma cells stimulate the recruitment of dermal fibroblast toward the tumor microenvironment, and S1P induces the differentiation to myofibroblast/cancer-associated fibroblast (CAF). In turn, CAFs display increased SphK1 expression and release S1P that enhances melanoma migration (through S1PR3) and growth. CAF also express $\alpha$-smooth muscle actin ( $\alpha$-SMA) and secrete growth factors, extracellular matrix (ECM) components, and metalloproteinases (MMP) that augment cancer progression and promote tumor metastasis.

Importantly, S1P-induced attenuation of NF- $\kappa \mathrm{B}$ activity in TAMs (118), but not in cancer cells, may be another mechanism of the tumor to elude the immune response of the host. On the other hand, although S1P-mediated induction of M2 macrophage polarization and angiogenesis correlates with cancer progression, it may also prove to be useful for bone regeneration and physiological situations that require wound repair (119). Thus, it is clear that targeting S1P as a macrophage modulator involves establishing a compromise between beneficial and harmful outcomes. The identification of the potential functions of S1P as master regulator of macrophage production and polarization is perhaps one of the most challenging tasks for this field in the coming years. Indeed, reprogramming TAMs phenotype to activate antitumor response is a proposed strategy for cancer treatment that warrants further clinical evaluation.

\section{Resident Mast Cell Functions and Phenotypic Plasticity}

Mast cells are tissue-dwelling cells, thus, de facto components of the tumor microenvironment and endowed with immunomodulating functions through the production of numerous mediators, including S1P $(120,121)$. Human and mouse studies have established pro- or antitumorigenic functions for MC (122). Increased number of MC has been observed in all solid tumors, such as melanoma (123), prostate (124-127), colorectal (128) and pancreatic (129) adenocarcinomas, and NSCLC (130). Confusingly, MC elevation has been described as indicative of a poor $(124,127)$ or a good $(125,126)$ prognosis. For example, in prostate cancer, increased number of MC around, but not within, cancer foci positively correlated with advanced stage (124), whereas high intratumoral MC density was accompanied with a 
good prognosis (126). Thus, it is suggested that MC functions are likely to be determined by the organ affected with and the stage of tumor, in addition to their location in the tissues relative to tumor foci (122).

Mast cells may differentiate into two subsets depending upon the tissue they populate and the microenvironmental conditions, as defined by the protease repertoire harbored within cytoplasmic granules: connective tissue or serosal MC express tryptase and chymase, whereas mucosal MC are single positive for tryptase (120). Importantly, MC-derived proteases can activate matrix metalloproteinases (MMP) that are critical to tumor growth and metastasis, and we recently reported that S1P-mediated MC activation triggered substantial release of MMP and pro-angiogenic VEGF (131). We and others have shown that MC can produce S1P $(3,132)$. Therefore, it is tempting to speculate that MC could be one of the initial and prime cellular sources of local S1P in tissues that may trigger tumorigenesis.

It is noteworthy that augmented levels of S1P may act in a paracrine manner on the neighboring cells and also in an autocrine manner on MC, leading to further MC activation. Our laboratory has discovered key contributions of $\mathrm{MC}$ to the inception and perpetuation of multi-organ manifestations of inflammation, including tissue remodeling, perivascular edema, and chemoattraction of T lymphocytes through signaling of S1P $(105,120$, 133). As previously mentioned, a link between chronic inflammation and cancer was originally described more than 100 years ago, and MC could orchestrate the transition from inflammation to cancer. Interestingly, we discovered that exposure to S1P led to human MC hyperplasia and chymase expression, in addition to MC activation (121), and chymase-expressing MC were hyperactive with increased mediator content and release and extended surface receptor expression $(121,134)$, also reported by others (135).

In sum, the presence of $\mathrm{MC}$ in tissues prior to cancer inception and their ability to produce and respond to S1P by secretion of tumor-influencing mediators may qualify $\mathrm{MC}$ as key regulators of the tumor microenvironment, pointing toward the MC/S1P axis as a promising interventional target to prevent cancer initiation and progression.

\section{S1P Functions in Other Immune Cells}

Even though most of the literature point to a crucial role of S1P in monocytes/macrophages recruitment, survival, and polarization, it has also been suggested that S1P modulates the function of other immune cells of the tumor microenvironment. Thus, while S1P acts as a chemoattractant of NK cells, it also inhibits its cytotoxic activity through a mechanism that involves the increase of cAMP levels and activation of protein kinase A (PKA) (136). Moreover, although Rolin et al. reported that S1P does not affect the cytotoxic activity of NK cells, they showed that S1P protects human myeloid leukemia K562 cells from NK cells-induced lysis through the activation of S1PR1 (137). Whereas these evidences indicate that S1P may contribute to tumor evasion from NK cells, on the other hand, S1P also inhibits NK-mediated cell lysis of immature monocyte-derived DCs (137), which may favor antigen presentation to T cells. Moreover, S1P enhances endocytosis and migration of mature DCs through S1PR3 engagement (138), an event that may increase immune response toward cancer cells. In addition, in the presence of S1P, monocytes differentiate into DCs that do not express CD1a and display reduced capability of stimulating T lymphocytes as compared with DCs that matured in the absence of S1P (139). Consequently, this duality in the role of S1P in NK and DCs in migration and phenotypic modulation deserves more attention to unequivocally establish its pathophysiological relevance.

The role of S1P on lymphocyte migration and egress from lymphoid organs has been extensively studied and resulted in the development of the S1PR1 functional agonist fingolimod for the treatment of autoimmune diseases such as MS (140). However, in the last years, many reports suggest distinct and, in some cases, conflicting functions of $\mathrm{S} 1 \mathrm{P}$ in $\mathrm{B}$ and $\mathrm{T}$ lymphocytes regarding cancer progression. Differential expression of S1PRs has a crucial function in $\mathrm{B}$ and $\mathrm{T}$ cell lymphocyte migration and activation. In diffuse large B-cell lymphoma (DLBCL) cell lines, expression of S1PR2 reduces tumor growth and is a good prognosis factor for patient survival (141). In addition, the modulation of S1PR1, S1PR2, and S1PR4 engagement regulates B cell circulation in patients with chronic lymphocytic leukemia (CLL) (142). Thus, while S1PR1 is expressed at low levels in CLL lymph nodes as compared with normal B cells (143), increased expression of S1PR1 correlates with signal transducer and activator of transcription 3 (STAT3) activation and survival in B-cell lymphoma (144). Furthermore, decreased expression of S1PR1 in CLL B cells impairs their egress from the peripheral lymphoid organs and enhances their survival (145).

Regulatory $\mathrm{T}$ cells (Tregs) have a crucial function in cancer progression since they suppress the antitumor activity of other immune cells. While fingolimod inhibition of Tregs proliferation may abrogate the suppressive role of these cells in the tumor microenvironment (146), it has more recently been shown that S1PR1 signaling activates STAT3, resulting in accumulation of Tregs and tumor growth in an orthotopic model of breast cancer (147). In that regard, the elucidation of the subjacent mechanisms involved in these opposite functions of S1P may be of great importance to overcome the immunological tolerance frequently observed in cancer progression.

In sum, in the last few years, it has become clearly evident that S1P modulates numerous aspects of immune cells. However, the discrepancy and complexity of its actions guarantee that more studies are needed to establish the role of this lipid in the immune cells that inhabit the tumor microenvironment.

\section{S1P and Cancer-Related Inflammatory Pathways}

A role of S1P in regulating NF- $\kappa$ B and STAT3 activation, two key signaling pathways that link cancer with inflammation, has been long suspected, but only recently uncovered. It has been reported that S1P can activate NF- $\kappa$ B through both intracellular and extracellular mechanisms. Receptor-mediated activation involved S1PR1/3 in different cell types $(115,148-153)$. Moreover, we have recently demonstrated that activation of NF- $\mathrm{BB}$ by extracellular S1P in melanoma cells involved both S1PR1 and S1PR2 and was inversely correlated with the expression of the actin-binding 
protein FlnA (89). Interestingly, FlnA physically interacts with SphK1 (16) and TNF receptor-associated factor 2 (TRAF2) (154). Certainly, we established that intracellular S1P generated by SphK1 was a required cofactor for TRAF2 E3 ubiquitin ligase activity, linking TNF signaling to NF- $\mathrm{KB}$ activation in melanoma cells (34). Our results were supported by other reports showing that TRAF-interacting protein (TRIP), a cellular-binding partner of TRAF2, abrogated TNF-induced NF- $\kappa$ B activation by inhibiting binding of S1P to TRAF2 and thus suppressing its E3 ubiquitin ligase activity (155). Altogether, it is clear that S1P is able to modulate, in distinct ways, the activation of $\mathrm{NF}-\mathrm{\kappa B}$ providing a link between chronic inflammation and cancer (156). Indeed, NF- $\kappa \mathrm{B}$ activation in macrophages also promoted the switch toward an M2 phenotype (157). Considering the role of S1P in M2 macrophage polarization, it will be interesting to determine whether or not the NF- $\mathrm{BB}$-induced anti-inflammatory switch in macrophages could be triggered by S1P present in the tumor microenvironment.

A connection between S1P and STAT3 activation has also been shown to be critical for tumor progression. A pivotal study established a direct relationship between S1PR1 and STAT3 expression in distinct tumors, including lymphoma, adenocarcinoma, melanoma, breast, and prostate cancer (158). These findings were further reinforced later to show that silencing of S1PR1 expression diminished expression of STAT3-regulated genes and inhibited tumor progression (144). Moreover, Silva et al. showed that in a mice model of cancer-induce anorexia, high levels of S1PR1 were correlated with augmented phosphorylation of STAT3 in the hypothalamus (159). Interestingly, treatment with FTY720 does not affect tumor growth, but reduces weight loss and increases survival. The link between S1P and STAT3 is not restricted to S1PR1; thus, pharmacological inhibition of SphK2 abrogated STAT3 phosphorylation, leading to decreased proliferation of cholangiocarcinoma cells (160), while in ER-negative breast cancer cells, SphK1 knockdown led to a significant reduction in leptin-induced STAT3 phosphorylation (161).

Over the last years, accumulating evidences have demonstrated that S1P signaling was crucial for persistent activation of STAT3 in epithelial/tumor cells in inflammation-associated colon cancer (162). Thus, targeted deletion of SPL in normal intestinal epithelial cells, which increases S1P levels, enhanced colitis-associated cancer through STAT3-modulated regulation of proinflammatory cytokines (72). Moreover, silencing of SPL in fibroblast also supported tumor progression. In an elegant study, Liang et al. demonstrated that S1P, derived from increased SphK1 expression in CRC, drove a malicious loop that involved NF- $\mathrm{BB}$ activation and IL-6 production with the subsequent induction of STAT3 and upregulation of S1PR1 (163). This mechanism is crucial to connect chronic inflammation with colon cancer.

\section{S1P Regulates Interactions between Different Cells from the Tumor Microenvironment}

The role of S1P in the tumor microenvironment has been recently highlighted by different studies that described how this lipid may modulate interactions between distinct cell types in the tumor.
Thus, expression of SphK1 in dermal fibroblasts enhanced tumor growth in a model of melanoma (164) (Figure 2B). In addition, SphK1-expressing melanoma cells secreted factors required for fibroblasts to myofibroblasts differentiation, strongly indicating that SphK1 was crucial for communication between stromal and cancer cells in melanoma (Figure 2B). Reciprocally, myofibroblasts released S1P and metalloproteinases that increased melanoma growth and metastasis, respectively (Figure 2B). $\mathrm{S} 1 \mathrm{P}$ also mediates mutual interactions in the pancreas between tumor and stromals cells, leading to tumor progression (165). Indeed, pancreatic cancer cells overexpress SphK1 and secrete S1P which, in turn, binds to S1PR2 and induces stromal cells to release MMP-9, in a mechanism controlled by NF- $\mathrm{KB}$ activation. This feed-forward loop further enhanced tumor cell migration and invasion in vitro and cancer growth in vivo. Also, Beach et al. (166) established that SphK1 acted as a critical mediator of differentiation and of TGF- $\beta$-induced activation of cancer-associated fibroblasts, a cell type that inhabits the tumor microenvironment and supports cancer progression. It was recently demonstrated that communication between cancer and stromal cells was dependent on systemic host-derived S1P rather than S1P generated in tumor cells (167). Importantly, only systemic S1P regulates lung metastasis. Altogether, these evidences strongly support that S1P may facilitate the communication between malignant and stromal cells to enhance tumor development.

\section{Role of S1P in Hypoxia}

The establishment of the appropriate microenvironment is decisive for survival of cancer cells. Hereof, hypoxia, a condition where the tissues are not adequately oxygenated, is a typical feature of solid tumor microenvironment $(168,169)$. Hypoxia is a consequence of increased oxygen consumption by abnormally proliferating cancer cells that triggers the formation of new atypical blood vessels resulting in defective blood perfusion. Interestingly, hypoxia may stimulate or inhibit proliferation depending on the cell type.

The oxygen-sensitive transcription factor hypoxia-inducible factor 1 alpha $(\mathrm{HIF} 1 \alpha)$ is the master regulator of the hypoxic response, and its expression is mainly regulated at the posttranslational level (168). Interestingly, many evidences indicate that S1P can regulate the activity and expression of HIF1 $\alpha$ (170) (Figure 3). In that regard, it has been shown that SphK1 and S1PR2 were required to stabilize HIF1 $\alpha$ in different cell types $(171,172)$. Although most of the literature indicates that S1P is involved in HIF $\alpha$ regulation, it has also been described that SphK1 activity may control HIF2 $\alpha$ expression and transcriptional activity through a phospholipase D (PLD)-driven mechanism in clear cell renal cell carcinoma (173).

Notably, hypoxia also sustains M2 macrophage polarization $(174,175)$. Considering that apoptotic cells release S1P $(106,110)$ that has been associated to HIF1 $\alpha$ activation in macrophages (176), it is tempting to hypothesize that macrophage's switch in hypoxia may be regulated by S1P signaling. Indeed, inhibition of S1P not only reduced hypoxia in vivo but also modified the structure of intratumoral vessels resulting in enhanced delivery of chemotherapeutic drugs (66). To emphasize the interconnection between the S1P and hypoxia pathways, it has been shown that S1P enhanced endothelial CD31-positive cell differentiation 


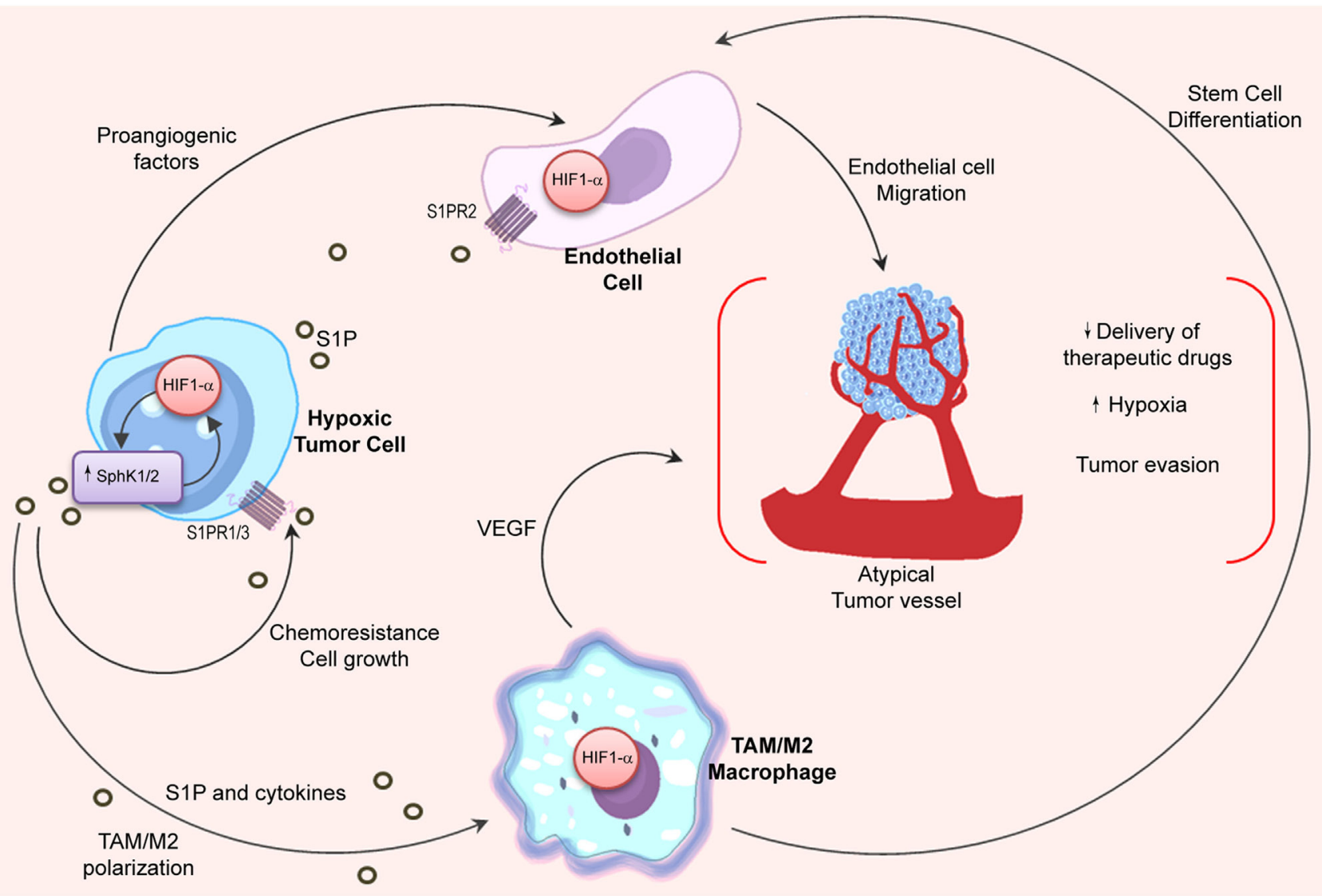

FIGURE 3 Relation between S1P and hypoxia in the tumor microenvironment. Angiogenic switch is crucial for tumor progression. HIF1 $\alpha$ stability in hypoxic tumor cells is associated to SphK1 expression, which is also regulated by HIF1 $\alpha$. In the tumor microenvironment, hypoxic cells release S1P and cytokines (oncostatin M, eotaxin, and IL-6) to induce M2 macrophage/TAM polarization. In turn, stabilization of HIF1 $\alpha$ in TAMs is important to stimulate stem cell differentiation and to release VEGF that supports angiogenesis. Importantly, S1P production in hypoxia increases endothelial cell migration through S1PR2 engagement and enhances the development of new vessels with deficient architecture that impairs the delivery of chemotherapeutic drugs.

(176), while hypoxia induced S1PR1 expression thus increasing migration of endothelial cells and neovascularization (177).

Recent findings suggest that the role of S1P in hypoxia can be more extensive than previously thought and may involve multiple pathways and mechanisms. In that regard, in glioma cells, while silencing of HIF $2 \alpha$ reduced expression of SphK1 and S1P levels, downregulation of HIF1 $\alpha$ increased SphK1 (178). Moreover, SphK2 activity was increased in A549 lung cancer cells cultured in hypoxia resulting in secretion of S1P that, in turn, protected against apoptosis and induced chemoresistance (179).

Although still warranting further studies, these results suggest that targeting S1P signaling in hypoxic conditions may be a potential mechanism to decrease angiogenesis and overcome resistance to chemotherapy.

\section{S1P AND CANCER THERAPEUTICS}

While many evidences in cellular and animal models suggest that targeting S1P axis may be of clinical benefit in cancer treatment, some compounds have only recently been utilized in clinical trials.
Likely, the most promising therapy involves Sonepcizumab (Asonep), the humanized version of the sphingomab antibody that specifically targets S1P. Sonepcizumab has recently completed Phase I clinical trials for treatment of solid tumors (NCT00661414).

Importantly, although many SphK1 inhibitors were shown to decrease angiogenesis, tumor growth, and proliferation (180), only one Phase I clinical trial with Safingol (SphK1 inhibitor) in combination with Cisplatin has been completed (NCT00084812) and indicated absence of toxicity (181). It is important to note that Safingol not only inhibits Sphk1 but also PKC, although with a slightly higher $\mathrm{K}_{\mathrm{i}}$.

Even though PF543, the most potent and selective SphK1 inhibitor described to date, decreased S1P levels, it had no effect on cancer cell viability (180), which discouraged the initiation of clinical trials with this compound. However, recent findings showing that PF-543 suppressed CRC xenograft growth and improved mice survival (86) may support renewed translation efforts. Of note, a Phase I clinical trial has already been completed with ABC294640 (SphK2 inhibitor) in patients with 
solid tumors (NCT01488513) and refractory/relapsed DLBCL (NCT02229981), but no results have been reported to date.

Considering the distinct functions of S1P in normal physiology, it is apparent that further studies will be needed to establish the safety and adverse effects associated with targeting the S1P axis.

\section{CONCLUDING REMARKS}

In the last few years, it has become clear that S1P exerts dual functions and may modulate both cancer and stromal cells. The role of S1P in cancer is not limited to enhance tumor growth, viability, and metastasis but S1P may also modulate the functional phenotype of immune cells that surround the tumor, which, in turn, may initiate bidirectional communication in the tumor microenvironment orchestrating cancer progression and chemoresistance. Thus, it is imperative to consider the tumor microenvironment as a key player when designing new potential

\section{REFERENCES}

1. Alvarez SE, Milstien S, Spiegel S. Autocrine and paracrine roles of sphingosine-1-phosphate. Trends Endocrinol Metab (2007) 18(8):300-7. doi:10.1016/j.tem.2007.07.005

2. Nijnik A, Clare S, Hale C, Chen J, Raisen C, Mottram L, et al. The role of sphingosine-1-phosphate transporter Spns2 in immune system function. J Immunol (2012) 189(1):102-11. doi:10.4049/jimmunol.1200282

3. Mitra P, Oskeritzian CA, Payne SG, Beaven MA, Milstien S, Spiegel S. Role of ABCC1 in export of sphingosine-1-phosphate from mast cells. Proc Natl Acad Sci U S A (2006) 103(44):16394-9. doi:10.1073/pnas.0603734103

4. Kihara Y, Maceyka M, Spiegel S, Chun J. Lysophospholipid receptor nomenclature review: IUPHAR review 8. Br J Pharmacol (2014) 171(15):3575-94. doi:10.1111/bph.12678

5. Spiegel S, Milstien S. The outs and the ins of sphingosine-1-phosphate in immunity. Nat Rev Immunol (2011) 11(6):403-15. doi:10.1038/nri2974

6. Pitson SM, Xia P, Leclercq TM, Moretti PA, Zebol JR, Lynn HE, et al. Phosphorylation-dependent translocation of sphingosine kinase to the plasma membrane drives its oncogenic signalling. JExp Med (2005) 201(1):49-54. doi:10.1084/jem.20040559

7. Jarman KE, Moretti PA, Zebol JR, Pitson SM. Translocation of sphingosine kinase 1 to the plasma membrane is mediated by calcium- and integrin-binding protein 1. J Biol Chem (2010) 285(1):483-92. doi:10.1074/jbc. M109.068395

8. Neubauer HA, Pitson SM. Roles, regulation and inhibitors of sphingosine kinase 2. FEBS J (2013) 280(21):5317-36. doi:10.1111/febs.12314

9. Hait NC, Bellamy A, Milstien S, Kordula T, Spiegel S. Sphingosine kinase type 2 activation by ERK-mediated phosphorylation. J Biol Chem (2007) 282:12058-65. doi:10.1074/jbc.M609559200

10. Ding G, Sonoda H, Yu H, Kajimoto T, Goparaju SK, Jahangeer S, et al. Protein kinase $\mathrm{D}$-mediated phosphorylation and nuclear export of sphingosine kinase 2. J Biol Chem (2007) 282(37):27493-502. doi:10.1074/jbc.M701641200

11. Maceyka M, Harikumar KB, Milstien S, Spiegel S. Sphingosine-1-phosphate signaling and its role in disease. Trends Cell Biol (2012) 22(1):50-60. doi:10.1016/j.tcb.2011.09.003

12. Snider AJ, Orr Gandy KA, Obeid LM. Sphingosine kinase: role in regulation of bioactive sphingolipid mediators in inflammation. Biochimie (2010) 92(6):707-15. doi:10.1016/j.biochi.2010.02.008

13. Matloubian M, Lo CG, Cinamon G, Lesneski MJ, Xu Y, Brinkmann V, et al. Lymphocyte egress from thymus and peripheral lymphoid organs is dependent on S1P receptor 1. Nature (2004) 427(6972):355-60. doi:10.1038/ nature02284

14. Kono M, Allende ML, Proia RL. Sphingosine-1-phosphate regulation of mammalian development. Biochim Biophys Acta (2008) 1781(9):435-41. doi:10.1016/j.bbalip.2008.07.001 therapies to overcome pitfalls associated with the current treatments of many human cancers.

\section{AUTHOR CONTRIBUTIONS}

YR reviewed the literature, wrote the first draft, organized the figures/tables, and revised critically the article. LC, MC, and AA reviewed the literature, drafted some parts, and revised critically the manuscript. CO and SA reviewed the literature, prepared the final version, made substantial contributions to the conception of the review, and revised critically the article. All the authors read and approved the final version of the manuscript.

\section{FUNDING}

This work was supported by grants from ANPCyT-Argentina PICT 1659-2010 to SA and from National Institutes of Health (NIH)/ NIAID R01 AI095494 and NIH/NIAMS R21 AR067996 to CO.

15. Pelletier D, Hafler DA. Fingolimod for multiple sclerosis. N Engl J Med (2012) 366(4):339-47. doi:10.1056/NEJMct1101691

16. Maceyka M, Alvarez SE, Milstien S, Spiegel S. Filamin A links sphingosine kinase 1 and sphingosine-1-phosphate receptor 1 at lamellipodia to orchestrate cell migration. Mol Cell Biol (2008) 28(18):5687-97. doi:10.1128/ MCB.00465-08

17. Shida D, Fang X, Kordula T, Takabe K, Lepine S, Alvarez SE, et al. Cross-talk between LPA1 and epidermal growth factor receptors mediates up-regulation of sphingosine kinase 1 to promote gastric cancer cell motility and invasion. Cancer Res (2008) 68(16):6569-77. doi:10.1158/0008-5472.CAN 08-0411

18. Long JS, Edwards J, Watson C, Tovey S, Mair KM, Schiff R, et al. Sphingosine kinase 1 induces tolerance to human epidermal growth factor receptor 2 and prevents formation of a migratory phenotype in response to sphingosine 1-phosphate in estrogen receptor-positive breast cancer cells. Mol Cell Biol (2010) 30(15):3827-41. doi:10.1128/MCB.01133-09

19. Kluk MJ, Ryan KP, Wang B, Zhang G, Rodig SJ, Sanchez T. Sphingosine-1phosphate receptor 1 in classical Hodgkin lymphoma: assessment of expression and role in cell migration. Lab Invest (2013) 93(4):462-71. doi:10.1038/ labinvest.2013.7

20. Goparaju SK, Jolly PS, Watterson KR, Bektas M, Alvarez S, Sarkar S, et al. The S1P2 receptor negatively regulates platelet-derived growth factor-induced motility and proliferation. Mol Cell Biol (2005) 25(10):4237-49. doi:10.1128/ MCB.25.10.4237-4249.2005

21. Malchinkhuu E, Sato K, Maehama T, Mogi C, Tomura H, Ishiuchi S, et al. S1P(2) receptors mediate inhibition of glioma cell migration through Rho signaling pathways independent of PTEN. Biochem Biophys Res Commun (2008) 366(4):963-8. doi:10.1016/j.bbrc.2007.12.054

22. Hyder CL, Kemppainen K, Isoniemi KO, Imanishi SY, Goto H, Inagaki M, et al. Sphingolipids inhibit vimentin-dependent cell migration. J Cell Sci (2015) 128(11):2057-69. doi:10.1242/jcs.160341

23. Arikawa K, Takuwa N, Yamaguchi H, Sugimoto N, Kitayama J, Nagawa H, et al. Ligand-dependent inhibition of B16 melanoma cell migration and invasion via endogenous S1P2 G protein-coupled receptor. Requirement of inhibition of cellular RAC activity. J Biol Chem (2003) 278(35):32841-51. doi:10.1074/jbc.M305024200

24. Miller AV, Alvarez SE, Spiegel S, Lebman DA. Sphingosine kinases and sphingosine-1-phosphate are critical for transforming growth factor beta-induced extracellular signal-regulated kinase 1 and 2 activation and promotion of migration and invasion of esophageal cancer cells. Mol Cell Biol (2008) 28(12):4142-51. doi:10.1128/MCB.01465-07

25. Liu R, Zhao R, Zhou X, Liang X, Campbell DJ, Zhang X, et al. Conjugated bile acids promote cholangiocarcinoma cell invasive growth through activation of sphingosine 1-phosphate receptor 2. Hepatology (2014) 60(3):908-18. doi:10.1002/hep.27085 
26. Kong Y, Wang H, Lin T, Wang S. Sphingosine-1-phosphate/S1P receptors signaling modulates cell migration in human bone marrow-derived mesenchymal stem cells. Mediators Inflamm (2014) 2014:565369. doi:10.1155/2014/565369

27. Dolezalova H, Shankar G, Huang MC, Bikle DD, Goetzl EJ. Biochemical regulation of breast cancer cell expression of S1P2 (Edg-5) and S1P3 (Edg-3) $\mathrm{G}$ protein-coupled receptors for sphingosine 1-phosphate. J Cell Biochem (2003) 88(4):732-43. doi:10.1002/jcb.10394

28. Wang H, Cai KY, Li W, Huang H. Sphingosine-1-phosphate induces the migration and angiogenesis of Epcs through the Akt signaling pathway via sphingosine-1-phosphate receptor 3/platelet-derived growth factor receptor-beta. Cell Mol Biol Lett (2015) 20(4):597-611. doi:10.1515/ cmble-2015-0035

29. Yamashita H, Kitayama J, Shida D, Yamaguchi H, Mori K, Osada M, et al. Sphingosine 1-phosphate receptor expression profile in human gastric cancer cells: differential regulation on the migration and proliferation. J Surg Res (2006) 130(1):80-7. doi:10.1016/j.jss.2005.08.004

30. Allende ML, Bektas M, Lee BG, Bonifacino E, Kang J, Tuymetova G, et al. Sphingosine-1-phosphate lyase deficiency produces a pro-inflammatory response while impairing neutrophil trafficking. JBiol Chem (2011) 286(9):7348-58. doi:10.1074/jbc.M110.171819

31. Dillmann C, Mora J, Olesch C, Brune B, Weigert A. S1PR4 is required for plasmacytoid dendritic cell differentiation. Biol Chem (2015) 396(6-7):775-82. doi:10.1515/hsz-2014-0271

32. Mayol K, Biajoux V, Marvel J, Balabanian K, Walzer T. Sequential desensitization of CXCR4 and S1P5 controls natural killer cell trafficking. Blood (2011) 118(18):4863-71. doi:10.1182/blood-2011-06-362574

33. Jenne CN, Enders A, Rivera R, Watson SR, Bankovich AJ, Pereira JP, et al. T-bet-dependent S1P5 expression in NK cells promotes egress from lymph nodes and bone marrow. J Exp Med (2009) 206(11):2469-81. doi:10.1084/ jem. 20090525

34. Alvarez SE, Harikumar KB, Hait NC, Allegood J, Strub GM, Kim EY, et al. Sphingosine-1-phosphate is a missing cofactor for the E3 ubiquitin ligase TRAF2. Nature (2010) 465(7301):1084-8. doi:10.1038/nature09128

35. Hait NC, Allegood J, Maceyka M, Strub GM, Harikumar KB, Singh SK, et al. Regulation of histone acetylation in the nucleus by sphingosine-1-phosphate. Science (2009) 325(5945):1254-7. doi:10.1126/science. 1176709

36. Strub GM, Paillard M, Liang J, Gomez L, Allegood JC, Hait NC, et al. Sphingosine-1-phosphate produced by sphingosine kinase 2 in mitochondria interacts with prohibitin 2 to regulate complex IV assembly and respiration. FASEB J (2011) 25(2):600-12. doi:10.1096/fj.10-167502

37. Parham KA, Zebol JR, Tooley KL, Sun WY, Moldenhauer LM, Cockshell MP, et al.Sphingosine 1-phosphate is a ligand for peroxisome proliferator-activated receptor-gammathatregulatesneoangiogenesis.FASEBJ(2015)29(9):3638-53. doi:10.1096/fi.14-261289

38. Mendelson K, Evans T, Hla T. Sphingosine 1-phosphate signalling. Development (2014) 141(1):5-9. doi:10.1242/dev.094805

39. Olivera A, Spiegel S. Sphingosine-1-phosphate as a second messenger in cell proliferation induced by PDGF and FCS mitogens. Nature (1993) 365:557-60. doi:10.1038/365557a0

40. Cuvillier O, Pirianov G, Kleuser B, Vanek PG, Coso OA, Gutkind S, et al. Suppression of ceramide-mediated programmed cell death by sphingosine-1-phosphate. Nature (1996) 381:800-3. doi:10.1038/381800a0

41. Newton J, Lima S, Maceyka M, Spiegel S. Revisiting the sphingolipid rheostat: evolving concepts in cancer therapy. Exp Cell Res (2015) 333(2):195-200. doi:10.1016/j.yexcr.2015.02.025

42. Zhang Y, Wang Y, Wan Z, Liu S, Cao Y, Zeng Z. Sphingosine kinase 1 and cancer: a systematic review and meta-analysis. PLoS One (2014) 9(2):e90362. doi:10.1371/journal.pone.0090362

43. Xu L, Zhang Y, Zou Y, Wang G, Fu Y. Concurrent targeting Akt and sphingosine kinase 1 by A-674563 in acute myeloid leukemia cells. Biochem Biophys Res Commun (2016) 472(4):662-8. doi:10.1016/j.bbrc. 2016.02.094

44. Dick TE, Hengst JA, Fox TE, Colledge AL, Kale VP, Sung SS, et al. The apoptotic mechanism of action of the sphingosine kinase 1 selective inhibitor SKI-178 in human acute myeloid leukemia cell lines. J Pharmacol Exp Ther (2015) 352(3):494-508. doi:10.1124/jpet.114.219659
45. Zhang D, Xia H, Zhang W, Fang B. The anti-ovarian cancer activity by WYE-132, a mTORC1/2 dual inhibitor. Tumour Biol (2016) 37(1):1327-36. doi:10.1007/s13277-015-3922-0

46. Wallington-Beddoe CT, Powell JA, Tong D, Pitson SM, Bradstock KF, Bendall LJ. Sphingosine kinase 2 promotes acute lymphoblastic leukemia by enhancing MYC expression. Cancer Res (2014) 74(10):2803-15. doi:10.1158/0008-5472.CAN-13-2732

47. Li J, Guan HY, Gong LY, Song LB, Zhang N, Wu J, et al. Clinical significance of sphingosine kinase-1 expression in human astrocytomas progression and overall patient survival. Clin Cancer Res (2008) 14(21):6996-7003. doi:10.1158/1078-0432.CCR-08-0754

48. Ohotski J, Long JS, Orange C, Elsberger B, Mallon E, Doughty J, et al. Expression of sphingosine 1-phosphate receptor 4 and sphingosine kinase 1 is associated with outcome in oestrogen receptor-negative breast cancer. Br J Cancer (2012) 106(8):1453-9. doi:10.1038/bjc.2012.98

49. Watson C, Long JS, Orange C, Tannahill CL, Mallon E, McGlynn LM, et al. High expression of sphingosine 1-phosphate receptors, S1P1 and S1P3, sphingosine kinase 1 , and extracellular signal-regulated kinase- $1 / 2$ is associated with development of tamoxifen resistance in estrogen receptor-positive breast cancer patients. Am J Pathol (2010) 177(5):2205-15. doi:10.2353/ ajpath.2010.100220

50. Xun C, Chen MB, Qi L, Tie-Ning Z, Peng X, Ning L, et al. Targeting sphingosine kinase 2 (SphK2) by ABC294640 inhibits colorectal cancer cell growth in vitro and in vivo. J Exp Clin Cancer Res (2015) 34:94. doi:10.1186/ s13046-015-0205-y

51. Long J, Xie Y, Yin J, Lu W, Fang S. SphK1 promotes tumor cell migration and invasion in colorectal cancer. Tumour Biol (2016) 37(5):6831-6. doi:10.1007/ s13277-015-4542-4

52. Li W, Yu CP, Xia JT, Zhang L, Weng GX, Zheng HQ, et al. Sphingosine kinase 1 is associated with gastric cancer progression and poor survival of patients. Clin Cancer Res (2009) 15(4):1393-9. doi:10.1158/1078-0432.CCR-08-1158

53. Bien-Moller S, Lange S, Holm T, Bohm A, Paland H, Kupper J, et al. Expression of S1P metabolizing enzymes and receptors correlate with survival time and regulate cell migration in glioblastoma multiforme. Oncotarget (2016) 7(11):13031-46. doi:10.18632/oncotarget.7366

54. Van Brocklyn JR, Jackson CA, Pearl DK, Kotur MS, Snyder PJ, Prior TW. Sphingosine kinase-1 expression correlates with poor survival of patients with glioblastoma multiforme: roles of sphingosine kinase isoforms in growth of glioblastoma cell lines. J Neuropathol Exp Neurol (2005) 64(8):695-705. doi:10.1097/01.jnen.0000175329.59092.2c

55. Xia P, Gamble JR, Wang L, Pitson SM, Moretti PA, Wattenberg BW, et al. An oncogenic role of sphingosine kinase. Curr Biol (2000) 10(23):1527-30. doi:10.1016/S0960-9822(00)00834-4

56. Shirai K, Kaneshiro T, Wada M, Furuya H, Bielawski J, Hannun YA, et al. A role of sphingosine kinase 1 in head and neck carcinogenesis. Cancer Prev Res (2011) 4(3):454-62. doi:10.1158/1940-6207.CAPR-10-0299

57. Uranbileg B, Ikeda H, Kurano M, Enooku K, Sato M, Saigusa D, et al. Increased mRNA levels of sphingosine kinases and S1P lyase and reduced levels of S1P were observed in hepatocellular carcinoma in association with poorer differentiation and earlier recurrence. PLoS One (2016) 11(2):e0149462. doi:10.1371/journal.pone.0149462

58. Cattoretti G, Mandelbaum J, Lee N, Chaves AH, Mahler AM, Chadburn A, et al. Targeted disruption of the S1P2 sphingosine 1-phosphate receptor gene leads to diffuse large B-cell lymphoma formation. Cancer Res (2009) 69(22):8686-92. doi:10.1158/0008-5472.CAN-09-1110

59. Lu Z, Xiao Z, Liu F, Cui M, Li W, Yang Z, et al. Long non-coding RNA HULC promotes tumor angiogenesis in liver cancer by up-regulating sphingosine kinase 1 (SPHK1). Oncotarget (2016) 7(1):241-54. doi:10.18632/ oncotarget.6280

60. Madhunapantula SV, Hengst J, Gowda R, Fox TE, Yun JK, Robertson GP. Targeting sphingosine kinase-1 to inhibit melanoma. Pigment Cell Melanoma Res (2012) 25(2):259-74. doi:10.1111/j.1755-148X.2012.00970.x

61. Li W, Tian Z, Qin H, Li N, Zhou X, Li J, et al. High expression of sphingosine kinase 1 is associated with poor prognosis in nasopharyngeal carcinoma. Biochem Biophys Res Commun (2015) 460(2):341-7. doi:10.1016/ j.bbrc.2015.03.036

62. Bayerl MG, Bruggeman RD, Conroy EJ, Hengst JA, King TS, Jimenez M, et al. Sphingosine kinase 1 protein and mRNA are overexpressed in non-Hodgkin 
lymphomas and are attractive targets for novel pharmacological interventions. Leuk Lymphoma (2008) 49(5):948-54. doi:10.1080/10428190801911654

63. Li J, Wu H, Li W, Yin L, Guo S, Xu X, et al. Downregulated miR-506 expression facilitates pancreatic cancer progression and chemoresistance via SPHK1/ Akt/NF-kappaB signaling. Oncogene (2016). doi:10.1038/onc.2016.90

64. Qiu W, Yang Z, Fan Y, Zheng Q. MicroRNA-613 inhibits cell growth, migration and invasion of papillary thyroid carcinoma by regulating SphK2. Oncotarget (2016). doi:10.18632/oncotarget.9530

65. Malavaud B, Pchejetski D, Mazerolles C, de Paiva GR, Calvet C, Doumerc N, et al. Sphingosine kinase- 1 activity and expression in human prostate cancer resection specimens. Eur J Cancer (2010) 46(18):3417-24. doi:10.1016/ j.ejca.2010.07.053

66. Ader I, Gstalder C, Bouquerel P, Golzio M, Andrieu G, Zalvidea S, et al. Neutralizing S1P inhibits intratumoral hypoxia, induces vascular remodelling and sensitizes to chemotherapy in prostate cancer. Oncotarget (2015) 6(15):13803-21. doi:10.18632/oncotarget.3144

67. Guan H, Liu L, Cai J, Liu J, Ye C, Li M, et al. Sphingosine kinase 1 is overexpressed and promotes proliferation in human thyroid cancer. Mol Endocrinol (2011) 25(11):1858-66. doi:10.1210/me.2011-1048

68. Li J, Song Z, Wang Y, Yin Y, Liu Y, Yuan R, et al. Overexpression of SphK1 enhances cell proliferation and invasion in triple-negative breast cancer via the PI3K/AKT signaling pathway. Tumour Biol (2016) 37(8):10587-93. doi:10.1007/s13277-016-4954-9

69. Kim HS, Yoon G, Ryu JY, Cho YJ, Choi JJ, Lee YY, et al. Sphingosine kinase 1 is a reliable prognostic factor and a novel therapeutic target for uterine cervical cancer. Oncotarget (2015) 6(29):26746-56. doi:10.18632/oncotarget.4818

70. Li MH, Sanchez T, Milne GL, Morrow JD, Hla T, Ferrer F. S1P/S1P2 signaling induces cyclooxygenase-2 expression in Wilms tumor. J Urol (2009) 181(3):1347-52. doi:10.1016/j.juro.2008.10.140

71. Oskouian B, Sooriyakumaran P, Borowsky AD, Crans A, Dillard-Telm L, Tam YY, et al. Sphingosine-1-phosphate lyase potentiates apoptosis via p53and p38-dependent pathways and is down-regulated in colon cancer. Proc Natl Acad Sci U S A (2006) 103(46):17384-9. doi:10.1073/pnas.0600050103

72. Degagne E, Pandurangan A, Bandhuvula P, Kumar A, Eltanawy A, Zhang M, et al. Sphingosine-1-phosphate lyase downregulation promotes colon carcinogenesis through STAT3-activated microRNAs. J Clin Invest (2014) 124(12):5368-84. doi:10.1172/JCI74188

73. Gao XY, Li L, Wang XH, Wen XZ, Ji K, Ye L, et al. Inhibition of sphingosine-1-phosphate phosphatase 1 promotes cancer cells migration in gastric cancer: clinical implications. Oncol Rep (2015) 34(4):1977-87. doi:10.3892/ or.2015.4162

74. Abuhusain HJ, Matin A, Qiao Q, Shen H, Kain N, Day BW, et al. A metabolic shift favoring sphingosine 1-phosphate at the expense of ceramide controls glioblastoma angiogenesis. J Biol Chem (2013) 288(52):37355-64. doi:10.1074/jbc.M113.494740

75. Bradley E, Dasgupta S, Jiang X, Zhao X, Zhu G, He Q, et al. Critical role of Spns2, a sphingosine-1-phosphate transporter, in lung cancer cell survival and migration. PLoS One (2014) 9(10):e110119. doi:10.1371/journal. pone.0110119

76. Brizuela L, Ader I, Mazerolles C, Bocquet M, Malavaud B, Cuvillier O. First evidence of sphingosine 1-phosphate lyase protein expression and activity downregulation in human neoplasm: implication for resistance to therapeutics in prostate cancer. Mol Cancer Ther (2012) 11(9):1841-51. doi:10.1158/1535-7163.MCT-12-0227

77. Lu Z, Zhang W, Gao S, Jiang Q, Xiao Z, Ye L, et al. MiR-506 suppresses liver cancer angiogenesis through targeting sphingosine kinase 1 (SPHK1) mRNA. Biochem Biophys Res Commun (2015) 468(1-2):8-13. doi:10.1016/ j.bbrc.2015.11.008

78. Xia J, Wu Z, Yu C, He W, Zheng H, He Y, et al. miR-124 inhibits cell proliferation in gastric cancer through down-regulation of SPHK1. J Pathol (2012) 227(4):470-80. doi:10.1002/path.4030

79. Zhang H, Wang Q, Zhao Q, Di W. MiR-124 inhibits the migration and invasion of ovarian cancer cells by targeting SphK1. J Ovarian Res (2013) 6(1):84. doi:10.1186/1757-2215-6-84

80. Antoon JW, White MD, Slaughter EM, Driver JL, Khalili HS, Elliott S, et al. Targeting NFkB mediated breast cancer chemoresistance through selective inhibition of sphingosine kinase-2. Cancer Biol Ther (2011) 11(7):678-89. doi:10.4161/cbt.11.7.14903
81. Schrecengost RS, Keller SN, Schiewer MJ, Knudsen KE, Smith CD. Downregulation of critical oncogenes by the selective SK2 inhibitor ABC294640 hinders prostate cancer progression. Mol Cancer Res (2015) 13(12):1591-601. doi:10.1158/1541-7786.MCR-14-0626

82. Sun E, Zhang W, Wang L, Wang A, Ma C, Lei M, et al. Down-regulation of Sphk2 suppresses bladder cancer progression. Tumour Biol (2016) 37(1):473-8. doi:10.1007/s13277-015-3818-z

83. Gao P, Smith CD. Ablation of sphingosine kinase-2 inhibits tumor cell proliferation and migration. Mol Cancer Res (2011) 9(11):1509-19. doi:10.1158/1541-7786.MCR-11-0336

84. Schnute ME, McReynolds MD, Kasten T, Yates M, Jerome G, Rains JW, et al. Modulation of cellular S1P levels with a novel, potent and specific inhibitor of sphingosine kinase-1. Biochem J (2012) 444(1):79-88. doi:10.1042/ BJ20111929

85. Rex K, Jeffries S, Brown ML, Carlson T, Coxon A, Fajardo F, et al. Sphingosine kinase activity is not required for tumor cell viability. PLoS One (2013) 8(7):e68328. doi:10.1371/journal.pone.0068328

86. Ju T, Gao D, Fang ZY. Targeting colorectal cancer cells by a novel sphingosine kinase 1 inhibitor PF-543. Biochem Biophys Res Commun (2016) 470(3):728-34. doi:10.1016/j.bbrc.2016.01.053

87. Guo YX, Ma YJ, Han L, Wang YJ, Han JA, Zhu Y. Role of sphingosine 1-phosphate in human pancreatic cancer cells proliferation and migration. Int J Clin Exp Med (2015) 8(11):20349-54.

88. Yamamoto S, Yako Y, Fujioka Y, Kajita M, Kameyama T, Kon S, et al. A role of the sphingosine-1-phosphate (S1P)-S1P receptor 2 pathway in epithelial defense against cancer (EDAC). Mol Biol Cell (2016) 27(3):491-9. doi:10.1091/mbc.E15-03-0161

89. Campos LS, Rodriguez YI, Leopoldino AM, Hait NC, Lopez Bergami P, Castro MG, et al. Filamin A expression negatively regulates sphingosine-1-phosphate-induced NF-kappaB activation in melanoma cells by inhibition of Akt signaling. Mol Cell Biol (2015) 36(2):320-9. doi:10.1128/ MCB.00554-15

90. Visentin B, Vekich JA, Sibbald BJ, Cavalli AL, Moreno KM, Matteo RG, et al. Validation of an anti-sphingosine-1-phosphate antibody as a potential therapeutic in reducing growth, invasion, and angiogenesis in multiple tumor lineages. Cancer Cell (2006) 9(3):225-38. doi:10.1016/j.ccr.2006.02.023

91. Zhang L, Wang X, Bullock AJ, Callea M, Shah H, Song J, et al. Anti-S1P antibody as a novel therapeutic strategy for VEGFR TKI-resistant renal cancer. Clin Cancer Res (2015) 21(8):1925-34. doi:10.1158/1078-0432.CCR-14-2031

92. Purschke WG, Hoehlig K, Buchner K, Zboralski D, Schwoebel F, Vater $\mathrm{A}$, et al. Identification and characterization of a mirror-image oligonucleotide that binds and neutralizes sphingosine 1-phosphate, a central mediator of angiogenesis. Biochem J (2014) 462(1):153-62. doi:10.1042/ BJ20131422

93. Schneider G, Bryndza E, Abdel-Latif A, Ratajczak J, Maj M, Tarnowski M, et al. Bioactive lipids S1P and C1P are prometastatic factors in human rhabdomyosarcoma, and their tissue levels increase in response to radio/ chemotherapy. Mol Cancer Res (2013) 11(7):793-807. doi:10.1158/15417786.MCR-12-0600

94. Shi J, He YY, Sun JX, Guo WX, Li N, Xue J, et al. The impact of sphingosine kinase 1 on the prognosis of hepatocellular carcinoma patients with portal vein tumor thrombus. Ann Hepatol (2015) 14(2):198-206.

95. Nunes J, Naymark M, Sauer L, Muhammad A, Keun H, Sturge J, et al. Circulating sphingosine-1-phosphate and erythrocyte sphingosine kinase-1 activity as novel biomarkers for early prostate cancer detection. Br J Cancer (2012) 106(5):909-15. doi:10.1038/bjc.2012.14

96. Rosa R, Marciano R, Malapelle U, Formisano L, Nappi L, D’Amato C, et al. Sphingosine kinase 1 overexpression contributes to cetuximab resistance in human colorectal cancer models. Clin Cancer Res (2013) 19(1):138-47. doi:10.1158/1078-0432.CCR-12-1050

97. Gao H, Deng L. Sphingosine kinase-1 activation causes acquired resistance against sunitinib in renal cell carcinoma cells. Cell Biochem Biophys (2014) 68(2):419-25. doi:10.1007/s12013-013-9723-4

98. Matula K, Collie-Duguid E, Murray G, Parikh K, Grabsch H, Tan P, et al. Regulation of cellular sphingosine-1-phosphate by sphingosine kinase 1 and sphingosine-1-phopshate lyase determines chemotherapy resistance in gastroesophageal cancer. BMC Cancer (2015) 15:762. doi:10.1186/ s12885-015-1718-7 
99. Liu W, Ning J, Li C, Hu J, Meng Q, Lu H, et al. Overexpression of Sphk2 is associated with gefitinib resistance in non-small cell lung cancer. Tumour Biol (2016) 37(5):6331-6. doi:10.1007/s13277-015-4480-1

100. Ishitsuka A, Fujine E, Mizutani Y, Tawada C, Kanoh H, Banno Y, et al. FTY720 and cisplatin synergistically induce the death of cisplatin-resistant melanoma cells through the downregulation of the PI3K pathway and the decrease in epidermal growth factor receptor expression. Int J Mol Med (2014) 34(4):1169-74. doi:10.3892/ijmm.2014.1882

101. Balkwill F, Mantovani A. Inflammation and cancer: back to Virchow? Lancet (2001) 357(9255):539-45. doi:10.1016/S0140-6736(00)04046-0

102. Coussens LM, Werb Z. Inflammation and cancer. Nature (2002) 420(6917):860-7. doi:10.1038/nature01322

103. Hanahan D, Coussens LM. Accessories to the crime: functions of cells recruited to the tumor microenvironment. Cancer Cell (2012) 21(3):309-22. doi:10.1016/j.ccr.2012.02.022

104. Spiegel S, Milstien S. Sphingosine-1-phosphate: an enigmatic signalling lipid. Nat Rev Mol Cell Biol (2003) 4(5):397-407. doi:10.1038/nrm1103

105. Oskeritzian CA, Hait NC, Wedman P, Chumanevich A, Kolawole EM, Price MM, et al. The sphingosine-1-phosphate/sphingosine-1-phosphate receptor 2 axis regulates early airway T-cell infiltration in murine mast cell-dependent acute allergic responses. JAllergy Clin Immunol (2015) 135(4):1008.e-18.e. doi:10.1016/j.jaci.2014.10.044

106. Gude DR, Alvarez SE, Paugh SW, Mitra P, Yu J, Griffiths R, et al. Apoptosis induces expression of sphingosine kinase 1 to release sphingosine-1-phosphate as a "come-and-get-me" signal. FASEB J (2008) 22(8):2629-38. doi:10.1096/fj.08-107169

107. Weichand B, Weis N, Weigert A, Grossmann N, Levkau B, Brune B. Apoptotic cells enhance sphingosine-1-phosphate receptor 1 dependent macrophage migration. Eur J Immunol (2013) 43(12):3306-13. doi:10.1002/eji.201343441

108. Luo B, Gan W, Liu Z, Shen Z, Wang J, Shi R, et al. Erythropoeitin signaling in macrophages promotes dying cell clearance and immune tolerance. Immunity (2016) 44(2):287-302. doi:10.1016/j.immuni.2016.01.002

109. Ley S, Weigert A, Weichand B, Henke N, Mille-Baker B, Janssen RA, et al. The role of TRKA signaling in IL-10 production by apoptotic tumor cell-activated macrophages. Oncogene (2013) 32(5):631-40. doi:10.1038/onc.2012.77

110. Weigert A, Tzieply N, von Knethen A, Johann AM, Schmidt H, Geisslinger G, et al. Tumor cell apoptosis polarizes macrophages: role of sphingosine-1-phosphate. Mol Biol Cell (2007) 8:3810-9. doi:10.1091/mbc.E06-12-1096

111. Sola A, Weigert A, Jung M, Vinuesa E, Brecht K, Weis N, et al. Sphingosine1-phosphate signalling induces the production of Lcn-2 by macrophages to promote kidney regeneration. J Pathol (2011) 225(4):597-608. doi:10.1002/ path. 2982

112. Brecht K, Weigert A, Hu J, Popp R, Fisslthaler B, Korff T, et al. Macrophages programmed by apoptotic cells promote angiogenesis via prostaglandin E2. FASEB J (2011) 25(7):2408-17. doi:10.1096/fi.10-179473

113. Weigert A, Johann AM, von Knethen A, Schmidt H, Geisslinger G, Brune B. Apoptotic cells promote macrophage survival by releasing the antiapoptotic mediator sphingosine-1-phosphate. Blood (2006) 108(5):1635-42. doi:10.1182/blood-2006-04-014852

114. Weigert A, Schiffmann S, Sekar D, Ley S, Menrad H, Werno C, et al. Sphingosine kinase 2 deficient tumor xenografts show impaired growth and fail to polarize macrophages towards an anti-inflammatory phenotype. Int J Cancer (2009) 125(9):2114-21. doi:10.1002/ijc.24594

115. He H, Zhang S, Tighe S, Son J, Tseng SC. Immobilized heavy chain-hyaluronic acid polarizes lipopolysaccharide-activated macrophages toward M2 phenotype. J Biol Chem (2013) 288(36):25792-803. doi:10.1074/jbc.M113.479584

116. Cortez-Retamozo V, Etzrodt M, Newton A, Ryan R, Pucci F, Sio SW, et al. Angiotensin II drives the production of tumor-promoting macrophages. Immunity (2013) 38(2):296-308. doi:10.1016/j.immuni.2012.10.015

117. Park SJ, Lee KP, Kang S, Lee J, Sato K, Chung HY, et al. Sphingosine 1-phosphate induced anti-atherogenic and atheroprotective M2 macrophage polarization through IL-4. Cell Signal (2014) 26(10):2249-58. doi:10.1016/ j.cellsig.2014.07.009

118. Hughes JE, Srinivasan S, Lynch KR, Proia RL, Ferdek P, Hedrick CC. Sphingosine-1-phosphate induces an antiinflammatory phenotype in macrophages. CircRes (2008) 102(8):950-8. doi:10.1161/CIRCRESAHA.107.170779

119. Das A, Segar CE, Hughley BB, Bowers DT, Botchwey EA. The promotion of mandibular defect healing by the targeting of S1P receptors and the recruitment of alternatively activated macrophages. Biomaterials (2013) 34(38):9853-62. doi:10.1016/j.biomaterials.2013.08.015

120. Oskeritzian CA. Mast cell plasticity and sphingosine-1-phosphate in immunity, inflammation and cancer. Mol Immunol (2015) 63(1):104-12. doi:10.1016/j.molimm.2014.03.018

121. Price MM, Oskeritzian CA, Milstien S, Spiegel S. Sphingosine-1-phosphate synthesis and functions in mast cells. Future Lipidol (2008) 3(6):665-74. doi:10.2217/17460875.3.6.665

122. Marichal T, Tsai M, Galli SJ. Mast cells: potential positive and negative roles in tumor biology. Cancer Immunol Res (2013) 1(5):269-79. doi:10.1158/23266066.CIR-13-0119

123. Toth-Jakatics R, Jimi S, Takebayashi S, Kawamoto N. Cutaneous malignant melanoma: correlation between neovascularization and peritumor accumulation of mast cells overexpressing vascular endothelial growth factor. Hum Pathol (2000) 31(8):955-60. doi:10.1053/hupa.2000.16658

124. Nonomura N, Takayama H, Nishimura K, Oka D, Nakai Y, Shiba M, et al. Decreased number of mast cells infiltrating into needle biopsy specimens leads to a better prognosis of prostate cancer. Br J Cancer (2007) 97(7):952-6. doi:10.1038/sj.bjc.6603962

125. Johansson A, Rudolfsson S, Hammarsten P, Halin S, Pietras K, Jones J, et al. Mast cells are novel independent prognostic markers in prostate cancer and represent a target for therapy. Am J Pathol (2010) 177(2):1031-41. doi:10.2353/ajpath.2010.100070

126. Fleischmann A, Schlomm T, Kollermann J, Sekulic N, Huland H, Mirlacher $\mathrm{M}$, et al. Immunological microenvironment in prostate cancer: high mast cell densities are associated with favorable tumor characteristics and good prognosis. Prostate (2009) 69(9):976-81. doi:10.1002/pros.20948

127. Pittoni P, Tripodo C, Piconese S, Mauri G, Parenza M, Rigoni A, et al. Mast cell targeting hampers prostate adenocarcinoma development but promotes the occurrence of highly malignant neuroendocrine cancers. Cancer Res (2011) 71(18):5987-97. doi:10.1158/0008-5472.CAN-11-1637

128. Gulubova M, Vlaykova T. Prognostic significance of mast cell number and microvascular density for the survival of patients with primary colorectal cancer. J Gastroenterol Hepatol (2009) 24(7):1265-75. doi:10.1111/j.1440-1746.2007.05009.x

129. Strouch MJ, Cheon EC, Salabat MR, Krantz SB, Gounaris E, Melstrom LG, et al. Crosstalk between mast cells and pancreatic cancer cells contributes to pancreatic tumor progression. Clin Cancer Res (2010) 16(8):2257-65. doi:10.1158/1078-0432.CCR-09-1230

130. Carlini MJ, Dalurzo MC, Lastiri JM, Smith DE, Vasallo BC, Puricelli LI, et al. Mast cell phenotypes and microvessels in non-small cell lung cancer and its prognostic significance. Hum Pathol (2010) 41(5):697-705. doi:10.1016/ j.humpath.2009.04.029

131. Chumanevich A, Wedman P, Oskeritzian CA. Sphingosine-1-phosphate/ sphingosine-1-phosphate receptor 2 axis can promote mouse and human primary mast cell angiogenic potential through upregulation of vascular endothelial growth factor-A and matrix metalloproteinase-2. Mediators Inflamm (2016) 2016:1503206. doi:10.1155/2016/1503206

132. Jolly PS, Bektas M, Olivera A, Gonzalez-Espinosa C, Proia RL, Rivera J, et al. Transactivation of sphingosine-1-phosphate receptors by Fc\{epsilon\} $\mathrm{RI}$ triggering is required for normal mast cell degranulation and chemotaxis. J Exp Med (2004) 199(7):959-70. doi:10.1084/jem.20030680

133. Oskeritzian CA, Price MM, Hait NC, Kapitonov D, Falanga YT, Morales JK, et al. Essential roles of sphingosine-1-phosphate receptor 2 in human mast cell activation, anaphylaxis, and pulmonary edema. JExp Med (2010) 207(3):465-74. doi:10.1084/jem.20091513

134. Oskeritzian CA, Zhao W, Min HK, Xia HZ, Pozez A, Kiev J, et al. Surface CD88 functionally distinguishes the MCTC from the MCT type of human lung mast cell. J Allergy Clin Immunol (2005) 115(6):1162-8. doi:10.1016/ j.jaci.2005.02.022

135. Olivera A, Kitamura Y, Wright LD, Allende ML, Chen W, Kaneko-Goto T, et al. Sphingosine-1-phosphate can promote mast cell hyper-reactivity through regulation of contactin-4 expression. J Leukoc Biol (2013) 94(5):1013-24. doi: $10.1189 / \mathrm{jlb} .0313163$

136. Lagadari M, Lehmann K, Ziemer M, Truta-Feles K, Berod L, Idzko M, et al. Sphingosine-1-phosphate inhibits the cytotoxic activity of NK cells via Gs protein-mediated signalling. Int J Oncol (2009) 34(1):287-94. doi:10.3892/ ijo_00000151 
137. Rolin J, Sand KL, Knudsen E, Maghazachi AA. FTY720 and SEW2871 reverse the inhibitory effect of S1P on natural killer cell mediated lysis of K562 tumor cells and dendritic cells but not on cytokine release. Cancer Immunol Immunother (2010) 59(4):575-86. doi:10.1007/s00262-009-0775-7

138. Maeda Y, Matsuyuki H, Shimano K, Kataoka H, Sugahara K, Chiba K. Migration of CD4 T cells and dendritic cells toward sphingosine 1-phosphate (S1P) is mediated by different receptor subtypes: S1P regulates the functions of murine mature dendritic cells via S1P receptor type 3. J Immunol (2007) 178(6):3437-46. doi:10.4049/jimmunol.178.6.3437

139. Martino A, Volpe E, Auricchio G, Izzi V, Poccia F, Mariani F, et al. Sphingosine 1-phosphate interferes on the differentiation of human monocytes into competent dendritic cells. Scand J Immunol (2007) 65(1):84-91. doi:10.1111/j.1365-3083.2006.01860.x

140. Cyster JG, Schwab SR. Sphingosine-1-phosphate and lymphocyte egress from lymphoid organs. Annu Rev Immunol (2012) 30:69-94. doi:10.1146/ annurev-immunol-020711-075011

141. Flori M, Schmid CA, Sumrall ET, Tzankov A, Law CW, Robinson MD, et al. The hematopoietic oncoprotein FOXP1 promotes tumor cell survival in diffuse large B-cell lymphoma by repressing S1PR2 signaling. Blood (2016) 127(11):1438-48. doi:10.1182/blood-2015-08-662635

142. Sic H, Kraus H, Madl J, Flittner KA, von Munchow AL, Pieper K, et al. Sphingosine-1-phosphate receptors control B-cell migration through signaling components associated with primary immunodeficiencies, chronic lymphocytic leukemia, and multiple sclerosis. J Allergy Clin Immunol (2014) 134(2):420-8. doi:10.1016/j.jaci.2014.01.037

143. Till KJ, Pettitt AR, Slupsky JR. Expression of functional sphingosine-1 phosphate receptor-1 is reduced by B cell receptor signaling and increased by inhibition of PI3 kinase delta but not SYK or BTK in chronic lymphocytic leukemia cells. J Immunol (2015) 194(5):2439-46. doi:10.4049/ jimmunol.1402304

144. Liu Y, Deng J, Wang L, Lee H, Armstrong B, Scuto A, et al. S1PR1 is an effective target to block STAT3 signaling in activated B cell-like diffuse large B-cell lymphoma. Blood (2012) 120(7):1458-65. doi:10.1182/ blood-2011-12-399030

145. Capitani N, Patrussi L, Trentin L, Lucherini OM, Cannizzaro E, Migliaccio E, et al. S1P1 expression is controlled by the pro-oxidant activity of p66Shc and is impaired in B-CLL patients with unfavorable prognosis. Blood (2012) 120(22):4391-9. doi:10.1182/blood-2012-04-425959

146. Wolf AM, Eller K, Zeiser R, Durr C, Gerlach UV, Sixt M, et al. The sphingosine 1-phosphate receptor agonist FTY720 potently inhibits regulatory $\mathrm{T}$ cell proliferation in vitro and in vivo. J Immunol (2009) 183(6):3751-60. doi:10.4049/jimmunol.0901011

147. Priceman SJ, Shen S, Wang L, Deng J, Yue C, Kujawski M, et al. S1PR1 is crucial for accumulation of regulatory $\mathrm{T}$ cells in tumors via STAT3. Cell Rep (2014) 6(6):992-9. doi:10.1016/j.celrep.2014.02.016

148. Blom T,Bergelin N,Meinander A,LofC,SlotteJP,ErikssonJE, etal. Anautocrine sphingosine-1-phosphate signaling loop enhances NF-kappaB-activation and survival. BMC Cell Biol (2010) 11:45. doi:10.1186/1471-2121-11-45

149. Fernandez-Pisonero I, Duenas AI, Barreiro O, Montero O, Sanchez-Madrid F, Garcia-Rodriguez C. Lipopolysaccharide and sphingosine-1-phosphate cooperate to induce inflammatory molecules and leukocyte adhesion in endothelial cells. JImmunol (2012) 189(11):5402-10. doi:10.4049/ jimmunol.1201309

150. Hsieh HL, Wu CB, Sun CC, Liao CH, Lau YT, Yang CM. Sphingosine-1phosphate induces COX-2 expression via PI3K/Akt and p42/p44 MAPK pathways in rat vascular smooth muscle cells. J Cell Physiol (2006) 207:757-66. doi:10.1002/jcp.20621

151. Ando T, Ishiguro H, Kuwabara Y, Kimura M, Mitsui A, Kurehara H, et al. Expression of ACP6 is an independent prognostic factor for poor survival in patients with esophageal squamous cell carcinoma. Oncol Rep (2006) 15(6):1551-5. doi:10.3892/or.15.6.1551

152. Bardelmeijer HA, Ouwehand M, Beijnen JH, Schellens JH, van Tellingen O. Efficacy of novel P-glycoprotein inhibitors to increase the oral uptake of paclitaxel in mice. Invest New Drugs (2004) 22(3):219-29. doi:10.1023/B:DRUG.0000026248.45084.21

153. Siehler S, Manning DR. Pathways of transduction engaged by sphingosine 1-phosphate through G protein-coupled receptors. Biochim Biophys Acta (2002) 1582(1-3):94-9. doi:10.1016/S1388-1981(02)00142-7
154. Leonardi A, Ellinger-Ziegelbauer H, Franzoso G, Brown K, Siebenlist U. Physical and functional interaction of filamin (actin-binding protein-280) and tumor necrosis factor receptor-associated factor 2. J Biol Chem (2000) 275(1):271-8. doi:10.1074/jbc.275.1.271

155. Park ES, Choi S, Shin B, Yu J, Yu J, Hwang JM, et al. Tumor necrosis factor (TNF) receptor-associated factor (TRAF)-interacting protein (TRIP) negatively regulates the TRAF2 ubiquitin-dependent pathway by suppressing the TRAF2-sphingosine 1-phosphate (S1P) interaction. J Biol Chem (2015) 290(15):9660-73. doi:10.1074/jbc.M114.609685

156. Karin M. NF-kappaB as a critical link between inflammation and cancer. Cold Spring Harb Perspect Biol (2009) 1(5):a000141. doi:10.1101/cshperspect. a000141

157. Hagemann T, Lawrence T, McNeish I, Charles KA, Kulbe H, Thompson RG, et al. "Re-educating" tumor-associated macrophages by targeting NF-kappaB. J Exp Med (2008) 205(6):1261-8. doi:10.1084/jem.20080108

158. Lee H, Deng J, Kujawski M, Yang C, Liu Y, Herrmann A, et al. STAT3-induced S1PR1 expression is crucial for persistent STAT3 activation in tumors. Nat Med (2010) 16(12):1421-8. doi:10.1038/nm.2250

159. Silva VR, Micheletti TO, Pimentel GD, Katashima CK, Lenhare L, Morari J, et al. Hypothalamic S1P/S1PR1 axis controls energy homeostasis. Nat Commun (2014) 5:4859. doi:10.1038/ncomms5859

160. Ding X, Chaiteerakij R, Moser CD, Shaleh H, Boakye J, Chen G, et al. Antitumor effect of the novel sphingosine kinase 2 inhibitor ABC294640 is enhanced by inhibition of autophagy and by sorafenib in human cholangiocarcinoma cells. Oncotarget (2016) 7(15):20080-92. doi:10.18632/ oncotarget.7914

161. Alshaker H, Wang Q, Frampton AE, Krell J, Waxman J, Winkler M, et al. Sphingosine kinase 1 contributes to leptin-induced STAT3 phosphorylation through IL-6/gp130 transactivation in oestrogen receptor-negative breast cancer. Breast Cancer Res Treat (2015) 149(1):59-67. doi:10.1007/ s10549-014-3228-8

162. Nguyen AV, Wu YY, Lin EY. STAT3 and sphingosine-1-phosphate in inflammation-associated colorectal cancer. World J Gastroenterol (2014) 20(30):10279-87. doi:10.3748/wjg.v20.i30.10279

163. Liang J, Nagahashi M, Kim EY, Harikumar KB, Yamada A, Huang WC, et al. Sphingosine-1-phosphate links persistent STAT3 activation, chronic intestinal inflammation, and development of colitis-associated cancer. Cancer Cell (2013) 23(1):107-20. doi:10.1016/j.ccr.2012.11.013

164. Albinet V, Bats ML, Huwiler A, Rochaix P, Chevreau C, Segui B, et al. Dual role of sphingosine kinase-1 in promoting the differentiation of dermal fibroblasts and the dissemination of melanoma cells. Oncogene (2014) 33(26):3364-73. doi:10.1038/onc.2013.303

165. Bi Y, Li J, Ji B, Kang N, Yang L, Simonetto DA, et al. Sphingosine-1-phosphate mediates a reciprocal signaling pathway between stellate cells and cancer cells that promotespancreaticcancergrowth. AmJ Pathol(2014) 184(10):2791-802. doi:10.1016/j.ajpath.2014.06.023

166. Beach JA, Aspuria PJ, Cheon DJ, Lawrenson K, Agadjanian H, Walsh CS, et al. Sphingosine kinase 1 is required for TGF-beta mediated fibroblastto-myofibroblast differentiation in ovarian cancer. Oncotarget (2016) 7(4):4167-82. doi:10.18632/oncotarget.6703

167. Ponnusamy S, Selvam SP, Mehrotra S, Kawamori T, Snider AJ, Obeid LM, et al. Communication between host organism and cancer cells is transduced by systemic sphingosine kinase 1 /sphingosine 1 -phosphate signalling to regulate tumour metastasis. EMBO Mol Med (2012) 4(8):761-75. doi:10.1002/ emmm.201200244

168. LaGory EL, Giaccia AJ. The ever-expanding role of HIF in tumour and stromal biology. Nat Cell Biol (2016) 18(4):356-65. doi:10.1038/ ncb3330

169. Dayan F, Mazure NM, Brahimi-Horn MC, Pouyssegur J. A dialogue between the hypoxia-inducible factor and the tumor microenvironment. Cancer Microenviron (2008) 1(1):53-68. doi:10.1007/s12307-008-0006-3

170. Cuvillier O, Ader I, Bouquerel P, Brizuela L, Gstalder C, Malavaud B. Hypoxia, therapeutic resistance, and sphingosine 1-phosphate. Adv Cancer Res (2013) 117:117-41. doi:10.1016/B978-0-12-394274-6.00005-4

171. Ader I, Brizuela L, Bouquerel P, Malavaud B, Cuvillier O. Sphingosine kinase 1: a new modulator of hypoxia inducible factor lalpha during hypoxia in human cancer cells. Cancer Res (2008) 68(20):8635-42. doi:10.1158/00085472.CAN-08-0917 
172. Michaud MD, Robitaille GA, Gratton JP, Richard DE. Sphingosine-1phosphate: a novel nonhypoxic activator of hypoxia-inducible factor-1 in vascular cells. Arterioscler Thromb Vasc Biol (2009) 29(6):902-8. doi:10.1161/ ATVBAHA.109.185280

173. Bouquerel P, Gstalder C, Muller D, Laurent J, Brizuela L, Sabbadini RA, et al. Essential role for SphK1/S1P signaling to regulate hypoxia-inducible factor 2alpha expression and activity in cancer. Oncogenesis (2016) 5:e209. doi:10.1038/oncsis.2016.13

174. Tripathi C, Tewari BN, Kanchan RK, Baghel KS, Nautiyal N, Shrivastava R, et al. Macrophages are recruited to hypoxic tumor areas and acquire a pro-angiogenic M2-polarized phenotype via hypoxic cancer cell derived cytokines oncostatin M and eotaxin. Oncotarget (2014) 5(14):5350-68. doi:10.18632/oncotarget.2110

175. Zhang J, Cao J, Ma S, Dong R, Meng W, Ying M, et al. Tumor hypoxia enhances non-small cell lung cancer metastasis by selectively promoting macrophage M2 polarization through the activation of ERK signaling. Oncotarget (2014) 5(20):9664-77. doi:10.18632/oncotarget.1856

176. Herr B, Zhou J, Werno C, Menrad H, Namgaladze D, Weigert A, et al. The supernatant of apoptotic cells causes transcriptional activation of hypoxia-inducible factor-1alpha in macrophages via sphingosine-1-phosphate and transforming growth factor-beta. Blood (2009) 114(10):2140-8. doi:10.1182/ blood-2009-01-201889

177. Williams PA, Stilhano RS, To VP, Tran L, Wong K, Silva EA. Hypoxia augments outgrowth endothelial cell (OEC) sprouting and directed migration in response to sphingosine-1-phosphate (S1P). PLoS One (2015) 10(4):e0123437. doi:10.1371/journal.pone.0123437
178. Anelli VV, Gault CR, Cheng AB, Obeid LM. Sphingosine kinase 1 is up-regulated during hypoxia in U87MG glioma cells: role of hypoxia-inducible factors 1 and 2. J Biol Chem (2008) 283(6):3365-75. doi:10.1074/jbc. M708241200

179. Schnitzer SE, Weigert A, Zhou J, Brune B. Hypoxia enhances sphingosine kinase 2 activity and provokes sphingosine-1-phosphate-mediated chemoresistance in A549 lung cancer cells. Mol Cancer Res (2009) 7(3):393-401. doi:10.1158/1541-7786.MCR-08-0156

180. Kunkel GT, Maceyka M, Milstien S, Spiegel S. Targeting the sphingosine-1-phosphate axis in cancer, inflammation and beyond. Nat Rev Drug Discov (2013) 12(9):688-702. doi:10.1038/nrd4099

181. Dickson MA, Carvajal RD, Merrill AH, Gonen M, Cane LM, Schwartz GK. A phase I clinical trial of safingol in combination with cisplatin in advanced solid tumors. Clin Cancer Res (2011) 17(8):2484-92. doi:10.1158/1078-0432. CCR-10-2323

Conflict of Interest Statement: The authors declare that the research was conducted in the absence of any commercial or financial relationships that could be construed as a potential conflict of interest.

Copyright (C) 2016 Rodriguez, Campos, Castro, Aladhami, Oskeritzian and Alvarez. This is an open-access article distributed under the terms of the Creative Commons Attribution License (CC BY). The use, distribution or reproduction in other forums is permitted, provided the original author(s) or licensor are credited and that the original publication in this journal is cited, in accordance with accepted academic practice. No use, distribution or reproduction is permitted which does not comply with these terms. 